\title{
Partial Privatization and Bank Performance: Evidence from India
}

\author{
Subrata Sarkar (ssarkar@igidr.ac.in) \\ Professor \\ Indira Gandhi Institute of Development Research \\ Gen A K Vaidya Marg, Goregaon (E) \\ Mumbai - 400065, INDIA
}

and

\section{Rudra Sensarma (rsensarma@gmail.com) Corresponding Author}

Senior Lecturer

University of Hertfordshire Business School

Hatfield, Hertfordshire, AL109AB, UK

\begin{abstract}
This paper examines the impact of partial privatization on performance of state-owned banks using data from the Indian banking industry during the period 1986-2003. We test the hypothesis that privatization leads to improvement in performance even when the government retains controlling stakes. Employing the technique of stochastic frontier analysis, we obtain bank-specific estimates of total factor productivity which we consider as a measure of performance along with four accounting measures. We then employ panel regression models to assess the impact of partial privatization on these performance indicators. We find that partial privatization resulted in significant improvement in performance of state-owned banks. This finding is robust to alternative model specifications and different techniques for controlling potential selection bias. The results suggest that faced with political opposition to full privatization, even if the government does not relinquish control, the exposure to market discipline through partial privatization may be an effective way of improving performance of state-owned banks.
\end{abstract}

Keywords: Banking; Partial Privatization; Stochastic Frontier; Productivity; Performance.

Paper Type: Research Paper 


\section{Partial Privatization and Bank Performance: Evidence from India}

\section{Introduction}

Several studies have empirically examined the effect of privatization on firm performance. Studies have concentrated on various aspects of this issue such as the mode and extent of privatization, sources of public sector inefficiency, measures of firm performance and the various econometric issues therein. However the evidence on whether privatization leads to improvement in performance is mixed. A survey by Vining and Boardman (1992) found that out of 87 papers considered only 28 reported performance improvement after privatization. Even when privatization does work it is not clear whether it is a feasible approach in many contexts. For instance, political opposition to privatization may prevent outright sale of stateowned enterprises. Faced with such political hurdles, governments may often resort to partial privatization as an alternative.

Partial privatization may lead to improvements in firm performance if the managerial view of privatization holds. This view emphasizes the monitoring and disciplining roles of stock markets and the consequent benefits of improved managerial incentives even when the privatization is only partial (Holmstrom and Tirole, 1993). On the other hand a political view of privatization opines that there may not be any performance gains from partial privatization if the government retains control of the firms after privatization. In such a situation political interference would continue to hamper the performance of state-owned firms and the privatization would not yield any benefits (Shleifer and Vishny, 1997). Which of these two effects would ultimately dominate in the case of partially privatized firms is not clear from the theoretical literature. There are other benefits of privatization such as improved access to external resources as creditors might perceive a privatized firm to be more credit-worthy than a state-owned firm that would receive political protection in case it defaults. Privatized firms 
would in general face lower costs of raising funds and are expected to potentially benefit from foreign direct investment and associated transfer of technology.

According to Gupta (2005), most studies on ownership and performance that find performance of firms improving after privatization consider cases where management control is transferred to private owners, but not much is known about the effectiveness of partial privatization. We attempt to examine this issue in the context of Indian banks which have undergone a programme of partial privatization since the launch of banking reforms in the early1990s. Indian banking offers a unique case study as it is characterized by the presence of public sector banks (i.e. fully state-owned as well as partially privatized banks) and private sector banks (domestic and foreign) thus covering the entire range of ownership types. Most studies have found that banks in India exhibited improvement in performance over the last two decades (see e.g. Kumbhakar and Sarkar, 2003; Sensarma, 2006). This has been attributed to the economic reforms of 1991 which engendered a series of measures such as interest rate deregulation and branch de-licensing. While the private banks outperformed the public sector banks in the earlier years, in recent years the latter have been able to bridge the gap by taking advantage of the deregulatory measures (Bhaumik and Dimova, 2004; Sensarma, 2006). However the public sector banks have been considered as a single group in these studies and no distinction was made between those banks that were partially privatized and those that remained fully state-owned.

India is an emerging economy where a shift from government control to a more liberalized economy in the 1990s meant that private participation in the economy has become significant. On the other hand, because of its vibrant democracy a strong political opposition exists that has prevented full privatization of many state-owned enterprises. This is especially 
true for state-owned banks due to their underlying social objectives which are perceived by the political opposition to be under threat if the banks were to be privatized. Owing to the political opposition to bank privatization, India has followed a piecemeal approach where the government has been relinquishing some of its stakes in one or a few banks every year. We study this partial privatization programme by examining bank performance over a long period of 1986 to 2003[1] which allows us to evaluate whether the managerial view or the political view has dominated in the case of Indian banks. In particular we are able to separately examine the roles of listing on the stock exchange and the magnitude of privatization. The very act of listing a state-owned bank on the stock exchange can generate market discipline as the Indian stock market regulator imposes strict disclosure norms on all listed entities. On the other hand the degree of divesture could influence the performance of banks as it proxies the extent of monitoring and disciplining the bank is subjected to by private shareholders.

Measurement of bank performance is a contentious issue in itself and there is an ongoing debate over what is a good measure. The productivity literature suggests that total factor productivity can be a useful measure of performance as it is not influenced by accounting practices. This is a popular approach in banking as total factor productivity can be computed based on the cost function and it is often argued that cost based measures are more appropriate for analyzing public sector units which may be more concerned with cost minimization rather than profit maximization (Kumbhakar and Sarkar, 2003). We assume that banks minimize costs by choosing the output level and therefore we adopt a cost based indicator of productivity defined using the Divisia index. In addition, we employ a host of accounting indicators of profitability and efficiency of banks. These indicators are justified on the grounds that one of the stated goals of banking sector reforms in India was to achieve improvement in profitability and efficiency. We study a total of four accounting indicators of 
profitability and efficiency to complement the Divisia index of total factor productivity in our analysis of partial privatization.

Analyzing data over the period 1986-2003, we find that partial privatization led to an improvement in performance of Indian state-owned banks with the effect being more persistent for total factor productivity than for accounting indicators. On an average, partially privatized banks experienced an increase of three to four percent in total factor productivity growth. These findings are robust to many alternative model specifications and controls for potential selection bias.

The rest of this paper is organized as follows. Section 2 provides a review of the relevant empirical literature. Section 3 presents a brief overview of the banking sector in India and the partial privatization programme. Section 4 discusses the data and the methodology employed. Section 5 contains the main empirical findings and their discussion. Section 6 highlights the robustness of the findings to alternative ways of accounting for potential endogeneity and Section 7 concludes the paper.

\section{Literature review}

The empirical literature on privatization has found significant performance gains from privatizing former state-owned firms. Boardman and Vining (1989) examined the performance of large non-US corporations in 1983 to conclude that private firms are more efficient than their public counterparts. Megginson, Nash and Van Randenborgh (1994) and D’Souza and Megginson (1999) compared pre- and post-privatization performance of a large number of firms from industrialized as well as developing countries to show that privatization resulted in significant gains in profitability, sales and efficiency. In the context of transition 
economies, Frydman et al. (1999) studied 200 firms from the Czech Republic, Hungary and Poland to show that for state-owned firms that are sold to outsiders (i.e. not managers or employees), privatization yields significant improvement in performance. Furthermore, the performance gains appear to be in terms of revenue enhancements rather than cost savings.

However the empirical literature specific to the banking industry does not provide unanimous evidence on the question of whether privatization helps to improve performance. Megginson (2005) provides an excellent survey of the empirical literature on bank privatization. Based on a review of a large number of studies he concludes that private banks are usually more efficient than state-owned banks. However in case of partial privatization, the effects on performance depend on institutional and regulatory environments. Bonin, Hasan and Wachtel (2005) studied cost and profit efficiency of 59 banks from six advanced transition countries and provide evidence in support of privatization. The analysis revealed that banks that are sold to a strategic foreign owner early in the period of the privatization programme exhibit better performance than state-owned banks and those banks that are privatized later. Boubakri et al. (2005) analyzed the privatization experience of 81 banks from 22 developing countries. Analysis of accounting indicators of performance revealed that the poor performers were selected for privatization and the impact of privatization on performance was ambiguous. While profitability increased, the impact on efficiency, risk exposure and capitalization largely depended on whether the control of the privatized bank rested with the government, foreign investors, local industrial groups or individuals.

To cite some country specific studies, Nakane and Weintraub (2005) estimated total factor productivity for 242 Brazilian banks and concluded that state-owned banks were less productive than their private counterparts and that privatization increased their productivity. 
Beck, Cull and Jerome (2005) studied the Nigerian banking system using data on accounting indicators of performance for 69 banks. They concluded that privatization led to performance improvement and those banks that continued to have minority government ownership performed worse than the fully privatized banks. On the other hand privatization has been shown to have negative effects in China (Chen, Li and Moshirian, 2005) and in Pakistan (Bonaccorsi di Patti and Hardy, 2005). Experience from Mexico suggests that bank privatization may fail unless there are strong institutions and well defined property rights (Haber, 2005). In fact Mexico's first experiment in privatization led to insolvency of the banks and the second experiment produced a risk-averse banking system. While most of these papers are concerned with whether privatization led to improvement in bank performance, the issue of partial privatization and bank performance has been scarcely studied.

Gupta (2005) studied the impact of partial privatization on firm performance. Employing data on Indian state-owned firms belonging to the manufacturing and the non-banking services sectors, she investigated the impact of partial privatization on performance. The performance variables considered were accounting indicators of profitability, productivity and investment. The analysis revealed that partial privatization did lead to improvement in performance. Since the government retained management control of these firms even after the partial privatization exercise, the improvement in performance could not be attributed to the elimination of political interference. Gupta (2005) attributed it to the amelioration of the agency problem associated with government ownership that got reduced with the stock market now enforcing managerial discipline and corporate control. In the case of Indian banks, Kumbhakar and Sarkar (2003) studied the impact of deregulation on the productivity of Indian banks and found that while productivity of private banks improved, public sector banks did not respond to deregulation. The issue of partial privatization of public sector 
banks was not considered by them. Mohan (2005) and Sathye (2005) used difference of means tests to conclude that financial parameters of performance for partially privatized banks in India were superior to those of public banks. However both these studies used only five years of data and did not consider the determinants of performance.

\section{Overview of Indian Banking}

The banking sector plays a crucial role in fostering economic growth, especially in an emerging economy such as India. Banks play an important role, inter alia, in the mobilization of savings and capital formation whose importance for an emerging economy cannot be overemphasized. The dominant presence of banking in the Indian economy can be gauged from the fact that aggregate deposits stood at 48 percent of GDP in 2002-03 and bank credit to the government and commercial sector stood at 26 percent and 33 percent of GDP respectively in 2002-03. Thus, in terms of size, banking occupies an important position in the economy. Prior to 1992, the banking sector in India was highly regulated and dominated by the public sector banks. With the developmental objectives of providing adequate credit, there were severe constraints on operational decisions. In addition, the banks were impeded by regulations on the pricing of financial products imposed by the banking regulator, viz. the Reserve Bank of India (RBI).

However, towards the early nineties the government realized that an excessive focus on quantitative achievements was making many banks inefficient, unprofitable and undercapitalized. Recognizing these problems, the RBI launched the banking sector reforms in 1992 on the recommendations of the first Narasimham committee on financial sector reforms (RBI, 1991). This led to the deregulation of entry, interest rates, branch de-licensing and allowed public sector banks to access the capital markets for raising equity. At the same time 
there were a number of changes in statutory norms, viz. a gradual reduction of the Cash Reserve Ratio (CRR) and the Statutory Liquidity Ratio (SLR), setting up of a minimum 8 percent Capital to Risk-weighted Assets Ratio (CRAR), and an imposition of stringent income recognition and provisioning norms. The second round of reforms in the banking sector followed the report of the second Narasimham committee (RBI, 1998) that laid stress on prudential measures like higher CRAR, allowing for market risk on government securities, stricter Non-Performing Assets (NPAs) norms, introduction of Assets-Liabilities management and risk management guidelines.

The banking sector reforms in India, initiated in 1992, were intended to impart enhanced efficiency, productivity and profitability into the system. One key element of the reforms process was the partial privatization of public sector banks. While the government retained controlling stakes, up to 49 percent of equity was sold to investors. However this was done in a piece-meal manner, with one or two banks getting listed in every year after 1993. Table 1 presents the timeline and extent of privatization of the public sector banks. Table 2 denotes the resulting shareholding pattern of the banks which suggests that while ownership is fairly diversified, foreign institutions ended up holding large stakes in the public sector banks and could act as an important source of market discipline.

\section{INSERT TABLES 1 AND 2 ABOUT HERE}

Even though the government continues to hold controlling stakes due to political reasons, it was felt that subjecting public sector banks to market discipline through stock exchange listing was an effective way of improving their performance as it provided a method of alleviating the agency problem arising out of government ownership. The stock market regulator has elaborate disclosure norms for new issues as well as continuing disclosures 
ranging from financial information to dividend policy, business risks and corporate governance requirements[2]. Banks intending to get listed on the stock exchange have to provide the auditor's report on their financial statements along with the management's discussion and analysis of financial conditions and results of operations. The business strategies as well as risks categorized as company specific and general factors have to be disclosed. Other requirements of the regulator include a due diligence certificate from a lead merchant banker, grading details from a credit rating agency, appointment of a compliance officer and details of outstanding litigations. Corporate governance requirements include details of management and shareholding structure, compensation of directors, information on audit committee, shareholder/ investor grievance committee etc.

Listed banks are therefore subject to stringent disclosures facilitating monitoring by investors which provides an alternative governance mechanism to the RBI's monitoring. The two are different in many aspects e.g. the RBI's focus is on prudential regulation and its compliance (and the information is not released to the public) rather than financial details and corporate governance (readily accessible by investors) which is a primary focus of the stock exchange disclosures. The Basel-II accord acknowledges that market discipline is an important governance mechanism which can complement the industry regulations and supervisory processes. Such disclosure norms and the consequent market discipline have made the public sector bank managements more cognizant of the market consequences of their activities, which may have led to the improvement in the performance of these banks (Mohan, 2006). On the other hand it may be argued that listing alone may not produce the desired effects unless a bank is fully privatized. This is because of the moral hazard generated by the implicit government guarantee in a partially privatized bank which could weaken the monitoring efforts of shareholders. The managers too are aware that the government may bail them out 
especially if the state is a large shareholder (Megginson, 2005). Therefore, the effects of partial privatization and listing on performance are hardly unambiguous. It is against this backdrop that we empirically examine the impact of the partial privatization programme on bank performance in India.

\section{Empirical Methodology and Data}

\subsection{Total Factor Productivity}

We use total factor productivity (TFP, henceforth) as our first measure of bank performance as "productivity gains are the dominant factor in post privatization outcomes" (La Porta and Lopez-de-Silanes, 1999). Following Kumbhakar and Lovell (2000), we estimate three components of TFP growth, viz. those attributable to technical progress, returns to scale and efficiency change and then aggregate them as

$$
T F \dot{P}=T F \dot{P}_{1}+T F \dot{P}_{2}+T F \dot{P}_{3}
$$

Until very recently, econometric models of TFP growth had ignored the last term i.e. the role of efficiency change. However, as Kumbhakar and Lovell (2000) purposefully argue, when individual production units vary greatly in terms of their cost or productive efficiency, ignoring this component is likely to give biased estimates of productivity growth. While the first two components of TFP growth i.e., technical progress and returns to scale, can be estimated from a standard cost function, the last component, i.e., efficiency change, requires the estimation of a cost frontier. Since the production technologies of banks are unknown $a$ priori, we estimate efficiency as the deviation from the efficient cost frontier where the bestpractice banks operate. To do that we consider the following stochastic cost frontier:

$\ln \mathrm{E}=\ln \mathrm{C}(\mathrm{Y}, \mathrm{W}, \mathrm{t})+\mathrm{U}+\mathrm{V}$ 
where, $\mathrm{E}=\mathrm{WX}$ is total expenditure, $\mathrm{X}=(\mathrm{x} 1, \ldots, \mathrm{xN})^{\prime}$ is a $(\mathrm{N} \times 1)$ vector of inputs, $\mathrm{W}=$ $(\mathrm{w} 1, \ldots, \mathrm{wN})^{\prime}$ is a $(\mathrm{N} \times 1)$ vector of input prices, $\mathrm{Y}=(\mathrm{y} 1, \ldots, \mathrm{yM})^{\prime}$ is a $(\mathrm{M} \times 1)$ vector of outputs, $\mathrm{t}$ is a time trend that proxies technical change, $\mathrm{C}(\mathrm{Y}, \mathrm{W}, \mathrm{t})$ is the deterministic kernel of the stochastic cost frontier, $\mathrm{U} \geq 0$ is the one-sided cost inefficiency term, and $\mathrm{V}$ is a random variable with zero mean. Appendix A explains how the TFP growth in equation (1) can be arrived at based on the stochastic cost frontier in equation (2).

\subsection{Estimation Procedure}

To arrive at the measure of TFP growth based on its three components we first need to estimate the stochastic cost frontier given in equation (2). This requires the specification of the random terms $\mathrm{U}$ and $\mathrm{V}$ and a functional form for the deterministic kernel $C(Y, W, t)$. We assume that the inefficiency term $\mathrm{u}_{i t}$ follows a truncated normal distribution with mean $\mu$ and constant variance, while the random term $\mathrm{v}_{i t}$ follows the usual normal distribution with a zero mean and constant variance[3]. Specifically, we assume, $\mathrm{u}_{i t} \sim \operatorname{iidN}{ }^{+}\left(\mu, \sigma^{2}{ }_{\mathrm{u}}\right)$ and $\mathrm{v}_{i t} \sim \operatorname{iidN}(0$, $\sigma^{2}$ ). For the deterministic kernel we employ the translog (transcendental logarithm) specification. The translog function (Christensen, Jorgenson and Lau, 1975) can be viewed as a second order approximation of any unknown function and it provides flexibility to a parametric functional form. Combining the error terms and the deterministic kernel, the cost frontier function is specified as:

$$
\begin{aligned}
& \ln C_{i t}=a_{0}+\sum_{m} a_{m} \ln y_{m i t}+\sum_{j} b_{j} \ln w_{j i t}+b_{t} t \\
& +\frac{1}{2}\left\{\sum_{m} \sum_{l} a_{m l} \ln y_{m i t} \ln y_{l i t}+\sum_{j} \sum_{k} b_{j k} \ln w_{j i t} \ln w_{k i t}+b_{t t} t^{2}\right\} \\
& +\sum_{m} \sum_{j} a_{m j} \ln y_{m i t} \ln w_{j i t}+\sum_{m} a_{m t} \ln y_{m i t} t+\sum_{j} b_{j t} \ln w_{j i t} t+u_{i t}+v_{i t}
\end{aligned}
$$

where $\mathrm{w}_{j i t}$ denotes the price of input $j$ and $\mathrm{y}_{m i t}$ denotes the amount of output $m$ produced by bank $i$ in period $t$, respectively. The dependent variable, operating cost, is the sum of 
establishment expenses and physical capital expenses[4]. We impose the standard restrictions of symmetry and linear homogeneity for estimating the parameters of equation (3):

$$
\mathrm{a}_{m l}=\mathrm{a}_{l m} \text { and } \mathrm{b}_{j k}=\mathrm{b}_{k j} ; \sum_{j} \mathrm{~b}_{j}=1, \sum_{j} \mathrm{~b}_{j k}=0 \forall k, \sum_{j} \mathrm{a}_{m j}=0 \forall m, \sum_{j} \mathrm{~b}_{j t}=0 .
$$

A widely debated issue in the banking literature is the definition of banking inputs and outputs, and more specifically the classification of deposits in this respect. The two alternative approaches to determining what constitutes inputs and outputs of banks are the production approach and the intermediation approach (Sealey and Lindley, 1977). The production approach considers labor and capital as inputs and number of processed accounts as outputs. The intermediation approach considers deposits as inputs and defines loans and investments as outputs. We adopt the production approach, which has been the most used approach in the Indian context (Kumbhakar and Sarkar, 2003), and thereby consider deposits to be an output of a bank. Finally, we also include the number of branches as an output variable. Branches are expected to control for many immeasurable attributes of a bank, e.g. quality of services and number of accounts serviced (Berg et al., 1993; Grifell-Tatje and Lovell, 1996)[5]. Accordingly, in this study, banks are modeled as multi-product firms that produce six outputs (fixed, saving and current deposits[6], loans, investments and branches) and employ two inputs (labor and capital).

The price of labor is defined as the ratio of established expenses to the total number of employees. The price of capital is measured as the ratio of physical capital expenses to fixed assets which is then used to normalize costs and input prices in order to impose the linear homogeneity restrictions. All the variables are defined in details in the Appendix Table B.1. The parameters of equation (3) are then estimated by the Maximum-Likelihood method using 
the FRONTIER (Version 4.1) software developed by Coelli (1996). The log-likelihood function of this model is available from Kumbhakar and Lovell (2000).

\subsection{Estimable Partial Privatization Regression}

Once the cost frontier is estimated and TFP growth is computed, we construct an index of TFP for every year and every bank as:

$$
T F P_{i t}=T F P_{i(t-1)}\left[1+T F \dot{P}_{i t}\right]
$$

The value of the index is set to 100 for the first year for all banks. Defining the logarithm of TFP index values as our first measure of performance, we regress it on the partial privatization variable as follows:

$$
\text { Performance }_{i t}=\alpha+\delta_{t}+\beta P P_{i t}+\gamma X_{i t}+\varepsilon_{i t}
$$

This equation is estimated using the fixed effects panel regression (within effects) model (see Wooldridge, 2002), where $i$ indexes banks, $t$ indexes years, $\alpha$ is the intercept, $\delta_{t}$ is a yearspecific fixed effect, $\beta$ is the coefficient of the partial privatization variable $P P, \gamma$ is the coefficient of a control variable $X$. We do not allow for bank-specific fixed effects as they lead to multicollinearity problems arising from the presence of a private sector dummy which we include in the model to control for those banks that belong to the private sector throughout our sample period.

We use various proxies to represent partial privatization $(P P)$ that we explain in details while presenting our empirical findings. In addition to TFP, we replace the performance variable in equation (4) with four different accounting ratios, viz. Operating Profit Ratio (OPR), Net Interest Margin (NIM), Operating Cost Ratio (OCR) and Staff Expense Ratio (SER). These variables are defined in the Appendix Table B.1. OPR is a simple measure of profitability as 
it indicates how a bank is able to generate revenues over and above its costs. NIM is a measure of a bank's competence in generate income from its core businesses i.e. interest bearing assets. Therefore, OPR and NIM offer us two metrics of a bank's performance in terms of its revenue generating abilities. OCR measures the extent of resources used by a bank and SER indicates its efficiency in labor usage. These two variables are suitable measures of operating efficiency. Therefore, in all we have five performance measures for estimating equation (4).

The year specific fixed effects account for unobserved year specific changes. This is particularly relevant in our case since the banking sector in India continues to undergo policy changes over the years. Moreover, the fixed effects would also help to control for competition effects that build up over time. Over the years as the banking sector experiences liberalization, intensified competition from private incumbents and the entry of de novo banks may affect performance of public sector banks. We expect the year specific fixed effects to capture such bank-invariant effects.

In equation (4) the main coefficient of interest is $\beta$ that is attached to the partial privatization variable $P P$. It indicates the effects on performance that is attributable to partial privatization over and above those caused by other regulatory changes and bank specific attributes. As for the sign of this coefficient, that would get determined by whether the managerial view (Holmstrom and Tirole, 1993) or the political view (Shleifer and Vishny, 1997) dominates. For instance if the former outweighs the latter i.e. if market discipline and incentives are strong even for partially privatized banks, then we can expect the coefficient to have a positive sign for the productivity and profitability measures. In other words, partial privatization would yield improvement in productivity and profitability. For OCR and SER 
we would then expect the coefficient to be negative as partial privatization would lead to cost savings for these banks. However in all the cases of partial privatization of Indian banks the government has so far retained control. This might mean that the political view dominates as political interference might continue to stifle the performance of the former state-owned banks.

Finally, we include control variables $X_{i t}$ to account for other sources of variations in performance. These include SIZE (logarithm of total assets) which proxies for the ability of smaller banks to respond more quickly to changes in market conditions in which case its coefficient would be negative in the partial privatization regressions. The proportion of rural branches (PROP_RUR) is considered as a proxy for the business opportunity, or the lack of it, faced by a bank in rural areas. Its coefficient would determine whether the investment in rural areas has been rewarding for banks. The proportion of non-interest income to total income (PROP_INT) controls for banks' diversification activities which are expected to benefit them through higher productivity and profitability.

\subsection{Data Source}

The accounting data of banks is taken from various issues of Financial Analysis of Banks and Performance Highlights of Banks published by the Indian Banks' Association. The ownership and listing data is taken from various issues of Report on Trends and Progress of Banking in India published by the Reserve Bank of India. Among the 27 public sector banks operating in India, we include all but 3 in our analysis. We exclude those 3 banks which got listed in the last year of the sample period (see Table 1). We include the domestic private banks as a control group to enable us to isolate the effects of partial privatization. There were 26 private banks during the sample period but incomplete information was available for private banks in 
some years leading to an unbalanced panel. We excluded new private banks which started operating in 1996 and hence cannot be a good control group like the older private banks. Moreover we do not include foreign banks as they operate in India as branches of their parent entities and are not listed on Indian stock exchanges like other private banks. Therefore they are not comparable with the Indian public sector and private banks when it comes to analyzing the impact of stock exchange listing on performance. A time period of 18 years is taken for each bank from the year 1986 to 2003[7].

Table 3 presents the share of banking assets that each bank group holds. Clearly the public sector banks are the dominant group with over 75 percent share of banking assets. But its share has been declining over the sample period while those of the private groups have been rising. Table 4 presents the descriptive statistics for the bank characteristics used in our empirical work. It appears that public sector banks are the larger group compared to private banks in terms of assets, deposits and loans. However among the public sector banks, those banks which were partially privatized are larger than those which were never partially privatized. Interestingly the former had a higher proportion of rural and semi-urban branches suggesting that they did not enjoy larger urban presence than the banks which were never partially privatized. But at the same time their proportion of non-interest income was higher indicating that they were focused on fee based activities and earnings from trading.

\section{INSERT TABLES 3 AND 4 ABOUT HERE}

\section{Empirical Findings}

We begin our discussion with the behavior of the TFP index and the accounting indicators as presented in Figure 1. The graphs indicate that public sector banks as well as private banks underwent improvement in productivity over the sample period. The period also witnessed 
improvement in profitability and efficiency as indicated by the increase in OPR and decline in OCR and SER. The improvements are particularly pronounced for the private banks relative to the public sector banks. However NIM remained stable for both bank groups.

\section{INSERT FIGURE 1 ABOUT HERE}

Using the five performance measures of the individual banks in each year, we estimate five partial privatization regressions based on equation (4). We use three specifications for the partial privatization $(P P)$ variable. These are (i) a trend variable that operates after a bank gets listed (LIST_TREND), (ii) a continuous variable to denote the extent of private ownership (PRIV_SHARE), and (iii) a dummy variable for stock exchange listing (LIST_DUM) that takes the value one once a bank gets partially privatized. These variables are designed to differently capture the roles of listing and ownership share. The variable LIST_TREND provides a way of examining whether there is persistence in the effect of partial privatization on performance. PRIV_SHARE is constructed to analyze whether performance is related to the extent of share ownership that is privately owned. LIST_DUM is designed to capture the average effect of the partial privatization programme on performance.

To address the concern of multicollinearity we present a correlation matrix of all the proposed independent variables in Table 5. While the three $P P$ variables seem to be highly correlated, there is very low correlation among the control variables and between the control and $P P$ variables. We do not include all the three $P P$ variables in the same model but use them in two combinations as described in the next paragraph. In any case we checked the variance inflation factors for each variable in each model; in none of the cases did the VIF turn out to be greater than 3 thereby indicating that our models did not suffer from 
multicollinearity problems. We correct for heteroscedasticity in all the models by estimating standard errors based on the Huber-White Sandwich estimator of variance.

\section{INSERT TABLES 5 AND 6 ABOUT HERE}

For each performance measure we estimate two variants of equation (4) using the alternative definitions of the $P P$ variable. The estimation results for these two models are presented in Tables 6 and 7. In Table 6, we present the results from regressing performance on PRIV_SHARE and LIST_TREND. We include a dummy variable PRIV_SECTOR for the private banks group along with the other control variables. The results reveal that the coefficient of PRIV_SHARE is positive for the TFP, OPR and NIM regressions and negative for the OCR and SER regressions. This indicates that higher divesture was associated with improved productivity (higher TFP) and profitability (higher OPR and NIM) while the

efficiency effects (in terms of OCR and SER) are not statistically significant. In the TFP regression the coefficient of IV_SHARE is 0.0007 and is significant only at 10 percent level of significance. On the other hand the effects of the extent of private ownership on OPR and NIM are stronger. In the OPR regression the coefficient of PRIV_SHARE is 0.0218 which is significant at the 1 percent level of significance while in the NIM regression the coefficient of PRIV_SHARE is 0.0194 which is significant at the 5 percent level. In sum we find statistically significant evidence of improved performance owing to higher divesture in the case of productivity and profitability.

The coefficient of LIST_TREND is statistically significant only in the TFP regression where it takes a positive value of 0.0220 . This indicates that in the years subsequent to their divesture, listed banks continued to exhibit higher productivity compared to unlisted banks. This suggests that improvement in productivity was not a one-off phenomenon or simply a 
"listing effect" (Gupta, 2005) but that the impact on productivity following partial privatization was permanent and sustained. Finally, comparing the relative magnitudes of the coefficients of PRIV_SHARE and LIST_TREND we observe that even though the number of significant coefficients is more for ownership share than for listing trend, the latter effect appears to be stronger in the only case where it is statistically significant. In the TFP regression the coefficient of LIST_TREND is 0.0220 while that of PRIV_SHARE is 0.0007 . It seems that while the magnitude of divesture may have been important in improving productivity and profitability, the very effect of listing on the stock exchange played a stronger disciplining role in improving productivity.

Moving to the control variables, we focus on those coefficients which are statistically significant in the estimations. First we observe that the coefficient of the private sector dummy in the TFP regression is -0.1008 which is statistically significant at the 1 percent level. This suggests that public sector banks had higher productivity than the private banks during the sample period[8]. The coefficient of this dummy variable is also significant in the OPR, NIM and SER regressions taking the values $0.6460,-0.3569$ and -0.5722 respectively. These values indicate that private banks had higher profitability and efficiency than the public sector banks. The proportion of rural branches seems to adversely impact costs as indicated by its positive and statistically significant coefficients of 1.1983 and 1.7585 in the OCR and SER regressions respectively. However the additional expenditure owing to rural branches appears to have paid rewards through higher profitability and productivity as evidenced by the NIM and TFP regressions where the coefficients of PROP_RUR are 1.7970 and 0.1000 respectively. 
The proportion of non-interest income is associated with higher efficiency as the coefficients of PROP_NINT are negative and statistically significant for the OCR and SER regressions (the coefficients are -0.0036 in both cases). However non-interest income seems to be associated with lower NIM (the corresponding coefficient being -0.0022) which is not surprising since banks with higher income from non-core businesses may have less focus on lending activities. Finally, the coefficients of SIZE suggest that bigger banks are less productive (the coefficient is -0.0135 in the TFP regression) and have lower spreads (the corresponding coefficient is -0.3309). It seems that smaller banks were better able to take advantage of the changing market conditions leading to higher productivity and interest income. However bigger banks are more efficient as indicated by the negative coefficients on SIZE in the SER regression which is -0.2732 .

In Table 7, we present the estimates of models comparing the roles of listing effect and ownership share by including the LIST_DUM variable along with PRIV_SHARE. The findings for PRIV_SHARE are similar to the previous results for profitability. For the SER regression we find that the coefficient of PRIV_SHARE is -0.0139 which is statistically significant at the 5 percent level. This suggests that the extent of divesture has a negative association with staff expenses. In case of LIST_DUM the only statistically significant coefficient appears in the TFP regression. Here it takes the positive value of 0.1663 and is significant at the 1 percent level. This indicates that the effect of listing was to improve the productivity of public sector banks and as before this effect appears to dominate the magnitude of divesture. The results for the control variables are similar to those obtained in the previous estimations in Table 6.

INSERT TABLE 7 ABOUT HERE 


\section{Endogeneity of Partial Privatization}

In the previous section we have estimated a variety of regressions to examine the impact of partial privatization on bank performance. However it could be argued that the improvements in performance suggested by our results were not the result of privatization but because the better performing banks were the ones to undergo divestment. In other words there could have been a selection bias in identifying which banks to privatize which in econometric terms would amount to endogeneity of our partial privatization variables. In this section we reexamine our results while controlling for potential selection bias. In order to do that, we start by re-estimating the partial privatization regressions but now consider only those banks that were partially privatized (see Tables 8 and 9). Thus these regressions are similar to the 'before and after' privatization analyses that are often found in this literature. We find that all the results from these regressions are qualitatively similar to our earlier results obtained using the full sample.

\section{INSERT TABLES 8 AND 9 ABOUT HERE}

In addition to the above regressions, we employ a variety of other techniques to control for potential selection bias. First we compare the performance of the partially privatized banks and the non-privatized banks using the t-test for difference in means and the Wilcoxon Z-test for difference in medians (see Appendix Table B.2). The data for the partially privatized banks in these tests are restricted only to the pre-privatization years. The results indicate that while the partially privatized banks had lower staff expense ratio, the non-privatized banks had higher productivity. In terms of the rest of the performance measures there does not seem to have been any statistically significant difference between the two groups. As a result, we can infer that there is no indication of selection bias in the partial privatization programme. 
Second, we employ the technique of instrumental variable estimation to control for the potential endogeneity of the partial privatization process. We use lags of OPR, NIM, OCR and SER as instruments for PRIV_SHARE in the TFP regression. Similarly for each regression we use the lags of the other performance measures as instruments. From the results we observe that even after allowing for endogeneity of PRIV_SHARE our finding that greater private share in ownership is associated with better performance continues to hold (see Appendix Table B.3). The statistically significant coefficients of PRIV_SHARE in the OPR and SER regressions suggest that greater divesture led to improved profitability as well as lower costs. Next we employ an alternative method for estimating instrumental variables through a two-stage procedure. First the decision to privatize is estimated as a probability (by regressing LIST_DUM on a set of instruments) which is then used to compute fitted values of privatization share. This is then used as the instrumental variable in the panel data regression. Other than the lagged performance variables, fiscal deficit and a stock exchange index (the Bombay Stock Exchange Sensitive Index) are used as instruments in this set of estimations. The results are presented in Table B.4. The coefficients of PRIV_SHARE in the OPR and SER regressions (0.0620 and -0.0482 respectively) are statistically significant at conventional levels as before. This shows that even after controlling for endogeneity using the two-stage procedure, we find that partially privatized banks experience improvements in profitability and efficiency.

Finally, we address the issue of endogeneity in an alternative fashion. Following Bartel and Harrison (2005), we use placebo leads for the share of partial privatization variable in order to control for any endogeneity present in this variable. We do this by adding a lead of PRIV_SHARE to the above estimated regressions (see Appendix Table B.5). We find that the lead variable is statistically insignificant in all but one case and our original result regarding 
the positive and statistically significant association between productivity and partial privatization remains robust. The only exception is the OPR regression where privatization may have been preceded by higher profitability. However in view of the results from all the alternative tests we have conducted, on balance we conclude that our main results are not affected by endogeneity problems.

\section{Conclusion}

The partial privatization programme in Indian banking since the early nineties was undertaken to improve the performance of public banks. While there have been a number of studies on bank performance in India, none so far have looked at the relationship between performance and partial privatization (other than examining the mean differences in performance as in Mohan, 2005 and Sathye, 2005). Partial privatization refers to the government divesting stakes in the public firm without relinquishing management control. Given political opposition to outright privatization, this has emerged as a feasible alternative for achieving some benefits of privatization. However the implications of partial privatization for performance are not very clear in policy debates as well as in the privatization literature.

In this context, the present paper employs the method of stochastic frontier analysis to study performance in Indian banking over a long time horizon of eighteen years that encompasses the government's partial privatization programme. We estimate TFP from a stochastic cost frontier and employ it as a measure of bank performance. In addition to TFP we employ four accounting indicators as alternative measures of performance. Using these five measures of performance, we study the impact of partial privatization on bank performance through panel regression models. 
The results may be summarized as follows. Public banks in India have exhibited improving performance during the period 1986-2003. A part of this improvement in performance can be attributed to partial privatization. We find that on an average, listed banks have significantly outperformed unlisted banks. This result corroborates the findings of Sarkar, Sarkar and Bhaumik (1998) who found that listed private banks in India outperform unlisted private banks, which in turn perform better than public banks. Here we have obtained a similar listing effect for public banks. Moreover we find that the effect of listing on performance is not a temporary phenomenon and is in fact persistent beyond the year of listing. Thus, performance of partially privatized banks continues to improve further after listing. Bhaumik and Dimova (2004) had noted a recent narrowing of the performance gap between public and private banks in India. Therefore, our results can be construed to suggest that the narrowing of the performance gap can be partly attributed to partial privatization of public banks. Our results also suggest that the extent to which government reduced its stakes in the public banks had a direct significant impact on the banks' performance. Thus higher is the extent of privatization better is the performance. These results support the managerial view of Holmstrom and Tirole, (1993) which suggests that even if the government partially privatizes state-owned firms, the forces of market discipline and consequent managerial incentives would be sufficient to bring about an improvement in performance. Our results are also confirm the findings of Mohan (2005) and Sathye (2005) who find improved performance of partially privatized banks by examining difference of means.

We control for potential endogeneity of partial privatization in a number of alternative ways. First we estimate the partial privatization regressions only for those banks that were eventually partially privatized. Next we compare the performance of the partially privatized banks with the rest of the banks. Then we use instrumental variables to allow for potential 
endogeneity in partial privatization. Finally we use placebo leads to account for the endogeneity. Based on our results, we conclude that even after accounting for endogeneity our results remain robust.

Governments across the globe have at various times taken recourse to privatizing state-owned firms for the purpose of revenue generation as well as for achieving increase in efficiency and competition. While in most developed countries this has taken the form of outright sale to private bidders (e.g. privatization in the U.K. in the 1980s), the political and social idiosyncrasies of developing countries might not permit such type of privatization. There is often strong political opposition to what is viewed as 'selling the family silver'. Even the government of the day may not be willing to let go of control over state-owned firms especially in an industry like banking which has traditionally been a tool for achieving developmental goals. In such instances partial privatization may be the only viable option as in the case of India's public sector banks.

The findings of this paper suggest that the post-privatization success of the partial privatization programme in India is clearly evidenced by improvements in performance. Our results add to the existing body of evidence on privatization by providing insights into the partial privatization in the banking industry of an emerging economy. We document that even when politicians might continue to exert some control over privatized banks, market pressures can reshape managerial incentives leading to increase in productivity, profitability and efficiency. 


\section{References}

Bartel, A. and Harrison, A. (2005), "Ownership versus Environment: Disentangling the Sources of Public Sector Inefficiency?", Review of Economics and Statistics, Vol. 87 No. 1, pp. 135-47.

Beck, T., Cull, R. and Afeikhena, J. (2005), "Bank Privatization and Performance: Empirical Evidence from Nigeria", Journal of Banking and Finance, Vol. 29 No. 8-9, pp. 23552379.

Bhaumik, S. K. and Dimova, R. (2004), "How Important is Ownership in a Market with Level Playing Field? The Indian Banking Sector Revisited", Journal of Comparative Economics, Vol. 32 No. 1, pp. 165-180.

Boardman, A.E. and Vining, A.R. (1989), “Ownership and Performance in Competitive Environments: A Comparison of the Performance of Private, Mixed, and State-Owned Enterprises", Journal of Law and Economics, Vol. 32 No. 1, pp. 1-33.

Bonaccorsi di Patti, E. and Hardy, D. (2005), "Financial Sector Liberalization, Bank Privatization and Efficiency: Evidence from Pakistan", Journal of Banking and Finance, Vol. 29 No. 8-9, pp. 2381-2406.

Bonin, J., Hasan, I. and Wachtel, P. (2005), "Privatization Matters: Bank Efficiency in Transition Countries", Journal of Banking and Finance, Vol. 29 No. 8-9, pp. 2155-2178.

Boubakri, N., Cosset, J., Fischer, K. and Guedhami, O. (2005), "Privatization and Bank Performance in Developing Countries", Journal of Banking and Finance, Vol. 29 No. 89, pp. 2015-2041.

Berg, S. A., Forsund, F. R., Hjalmarsson, L. and Suominen, M. (1993), "Banking efficiency in the Nordic countries", Journal of Banking and Finance, Vol. 17 No. 2-3, pp. 371-388. 
Chen, Z., Li, D. and Moshirian, F. (2005), “China's financial services industry: The intraindustry effects of the privatization of the Bank of China Hong Kong", Journal of Banking and Finance, Vol. 29 No. 8-9, pp. 2291-2324.

Christensen, Laurits R., Jorgenson, Dale W. and Lau, Lawrence J. (1975), “Transcendental Logarithmic Utility Functions”, American Economic Review, Vol. 65 No. 3, pp. 367-383.

Coelli, Tim J. (1996), “A Guide to FRONTIER Version 4.1: A Computer Program for Frontier Production Function Estimation", CEPA Working Paper 96/07, Department of Econometrics, University of New England, Armidale, Australia.

D’Souza, J. and Megginson, W.L. (1999), “The financial and operating performance of privatized firms during the 1990s", Journal of Finance, Vol. 54 No. 4, pp. 1397-1438.

Frydman, R., Gray, C., Hessel, M. and Rapaczynski, A. (1999), "When Does Privatization Work? The Impact of Private Ownership on Corporate Performance in Transition Economies" The Quarterly Journal of Economics, Vol. 114 No. 4, pp. 1153-1192

Grifell-Tatje, E. and Lovell, C.A.K. (1996), "Deregulation and Productivity Decline: The Case of Spanish Savings Banks”, European Economic Review, Vol. 40 No. 6, pp. 1281-1303.

Gupta, N. (2005), "Partial privatization and Firm performance", Journal of Finance, Vol. 60 No. 2, pp. 987-1015.

Haber, S. (2005), “Mexico’s Experiments with Bank Privatization and Liberalization, 19912003”, Journal of Banking and Finance, Vol. 29 No. 8-9, pp. 2325-2353.

Holmstrom, B. and Tirole, J. (1993), "Market Liquidity and Performance Monitoring", Journal of Political Economy, Vol. 101 No. 4, pp. 678-709.

Indian Banks' Association, Performance Highlights of Banks, Mumbai, various issues.

Indian Banks’ Association, Financial Analysis of Banks, Mumbai, various issues. 
Kumbhakar, S.C. and Lovell, C.A.K. (2000), Stochastic Frontier Analysis, Cambridge University Press, Cambridge.

Kumbhakar, S.C. and Sarkar, S. (2003), "Deregulation, Ownership, and Productivity Growth: Evidence from Indian Banks", Journal of Money, Credit and Banking, Vol. 35 No. 3, pp. 403-424.

La Porta, R. and Lopez-de-Silanes, F. (1999), "Benefits of privatization: Evidence from Mexico", Quarterly Journal of Economics, Vol. 114 No. 4, pp. 1193-1242.

Megginson, W.L. (2005), “The economics of bank privatization”, Journal of Finance, Vol. 29 No. 8-9, pp. 1931-1980.

Megginson, W.L., Nash, R.C. and Van Randenborgh, M. (1994), "The Financial and Operating Performance of Newly-Privatized Firms: An International Empirical Analysis”, Journal of Finance, Vol. 49 No. 2, pp. 403-452.

Mohan, R. (2005), Privatisation in India: Challening economic orthodoxy. Routledge.

Mohan, R. (2006), "Reforms, Productivity and Efficiency in Banking: The Indian Experience", Reserve Bank of India Bulletin, March.

Nakane, M.I. and Weintraub, D.B. (2005), "Bank Privatization and Productivity: Evidence for Brazil”, Journal of Banking and Finance, Vol. 29 No. 8-9, pp. 2259-2289.

Reserve Bank of India (1991), "Report of the Committee on Financial Sector Reforms".

Reserve Bank of India (1998), "Report of the Committee on Banking Sector Reforms".

Reserve Bank of India, Report on Trends and Progress of Banking in India, various issues.

Sarkar, S., Sarkar, J. and Bhaumik, S. K. (1998), "Does Ownership Always Matter? Evidence from the Banking Industry", Journal of Comparative Economics, Vol. 26 No. 2, pp. 262281. 
Sealey, C.W., Jr. and Lindley, J.T. (1977), "Inputs, Outputs, and a Theory of Production and Cost at Depository Financial Institutions”, Journal of Finance, Vol. 32 No. 4, pp. 12511266.

Sensarma, R. (2006), “Are Foreign Banks Always the Best? Comparison of State-Owned, Private and Foreign Banks in India”, Economic Modelling, Vol. 23 No. 4, pp. 717-735.

Shleifer, A. and Vishny, R. (1997), "A Survey of Corporate Governance”, Journal of Finance, Vol. 52 No. 2, pp. 737-783.

Vining, A.R. and Boardman, A.E. (1992), “Ownership versus Competition: Efficiency in Public Enterprise", Public Choice, Vol. 73 No. 2, pp. 205-39.

Wooldridge, J.M. (2002), Econometric analysis of cross section and panel data, The MIT Press, Cambridge, MA. 


\section{Figure 1: Performance Indicators for Public Sector and Private Sector Banks}

The figure presents a comparison of public and private sector banks based on the five performance indicators. TFP is the index of total factor productivity estimated from a stochastic cost frontier; OPR is operating profit ratio; NIM is net interest margin; OCR is operating cost ratio; SER is staff expense ratio.

\section{$\log ($ TFP)}

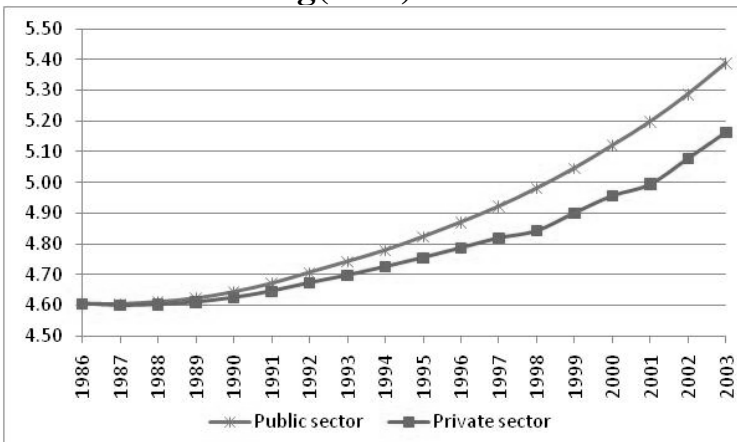

NIM

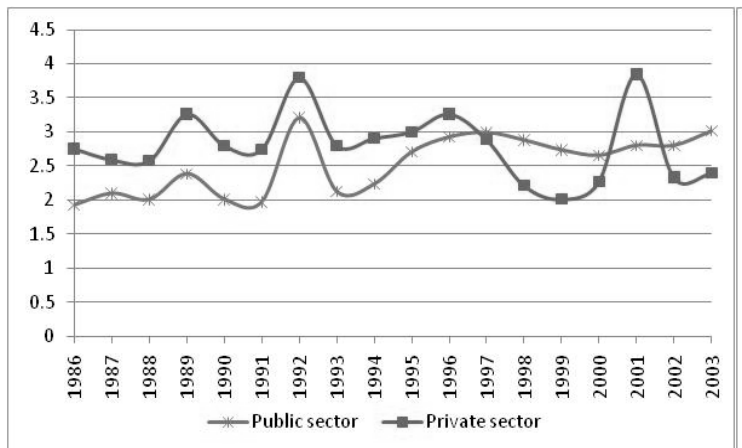

OPR

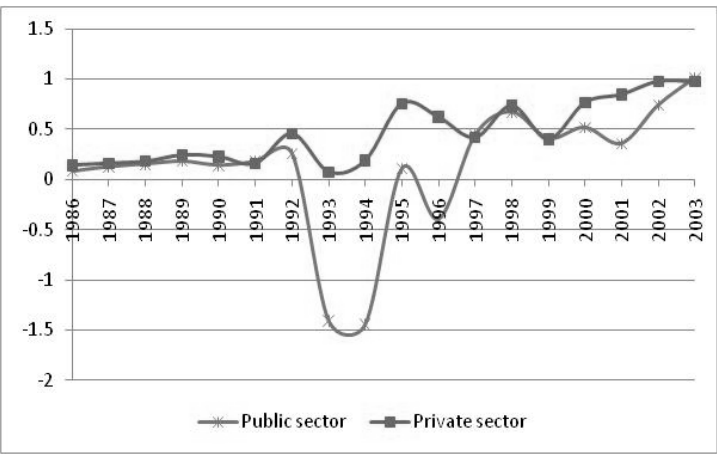

\section{OCR}

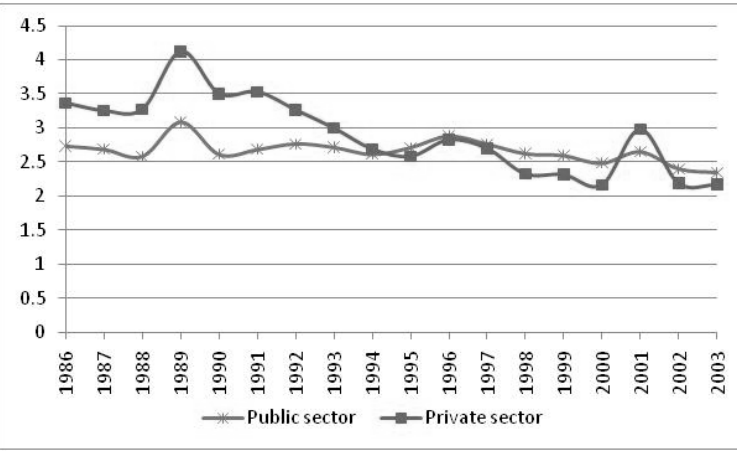

\section{SER}

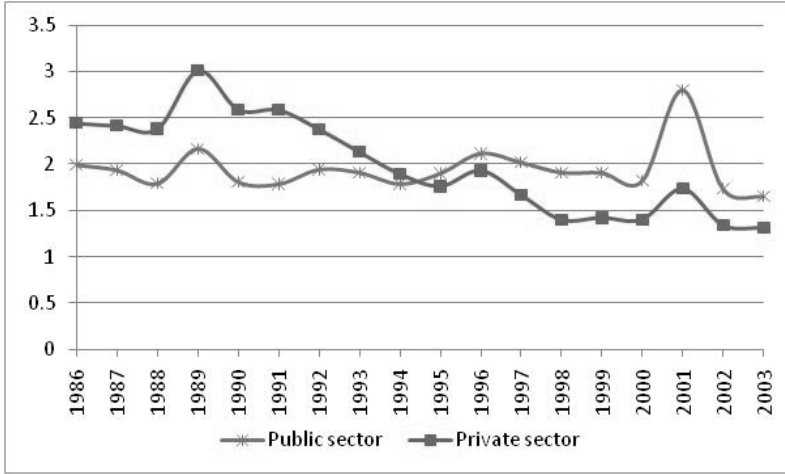




\section{Table 1: Timeline of Partial Privatization of Public Sector Banks till 2003}

This table shows the timeline of partial privatization till 2003 i.e. the last year of our period of analysis. Out of the 27 public sector banks in India, the 16 banks shown in this table were partially privatized and the remaining 11 were not (the names of the 11 banks that were not partially privatized are: State Bank of Hyderabad, State Bank of Indore, State Bank of Mysore, State Bank of Patiala, State Bank of Saurashtra, Bank of Maharashtra, Central Bank, Indian Bank, Punjab \& Sind Bank, UCO Bank, United Bank of India). State banks refer to those that were always state-owned viz. the State Bank of India and its associate banks. Nationalized banks refer to those that were taken into government ownership during the nationalization programmes in 1969 and 1980.

\begin{tabular}{lcc}
\hline Name of Bank & \multicolumn{2}{c}{ Partial Privatization Details } \\
\hline & Year Sold & Percentage of Equity Sold \\
State Bank of India and Its Associates & 1994 & $33.7 *$ \\
State Bank of India & 1998 & 25.0 \\
State Bank of Bikaner \& Jaipur & 1998 & 25.0 \\
State Bank of Travancore & & \\
& & \\
Nationalized Banks & 1995 & 33.5 \\
Oriental Bank of Commerce & 1997 & 33.8 \\
Bank of Baroda & 1997 & 30.7 \\
Bank of India & 1997 & 29.0 \\
Dena Bank & 1998 & 42.8 \\
Corporation Bank & 2000 & 26.5 \\
Syndicate Bank & 2001 & 33.4 \\
Andhra Bank & 2001 & 25.0 \\
Indian Overseas Bank & 2001 & 30.0 \\
Vijaya Bank & 2002 & 20.0 \\
Punjab National Bank & 2003 & 28.8 \\
Allahabad Bank & 2003 & 26.8 \\
Canara Bank & 2003 & 39.1 \\
Union Bank & & \\
\hline
\end{tabular}

Note: * a further 6.6 percent of equity was sold in the year 1997.

Source: RBI. 
Table 2: Shareholding Pattern of Public Sector Banks (end-March 2005)

This table shows the shareholding pattern of public sector banks in India in 2005 which is the earliest year for which this information is provided by the RBI's Reports on trends and progress in banking in India.

\begin{tabular}{|c|c|c|c|c|c|c|c|}
\hline & $\begin{array}{r}\text { Government } \\
\& \mathrm{RBI}\end{array}$ & FIs & $\begin{array}{r}\text { Foreign } \\
\text { FIs }\end{array}$ & $\begin{array}{r}\text { Other } \\
\text { Corporates }\end{array}$ & $\begin{array}{r}\text { Foreign } \\
\text { Corporates }\end{array}$ & Individuals & $\begin{array}{r}\text { Foreign } \\
\text { Individuals }\end{array}$ \\
\hline \multicolumn{8}{|l|}{ Nationalized Banks } \\
\hline Allahabad Bank & 71.2 & 3.8 & 0.8 & 3.1 & 0 & 21.1 & 0.1 \\
\hline Andhra Bank & 62.5 & 18.9 & 0 & 1.9 & 0 & 16.8 & 0 \\
\hline Bank of Baroda & 66.8 & 5.8 & 18 & 1.1 & 0 & 7.3 & 0.9 \\
\hline Bank of India & 69.5 & 4.3 & 10.8 & 1.4 & 2 & 10.8 & 1.2 \\
\hline Bank of Maharashtra & 76.8 & 4.2 & 0.8 & 2.3 & 0 & 15.9 & 0.1 \\
\hline Canara Bank & 73.2 & 3.2 & 15.3 & 1 & 0 & 7.3 & 0 \\
\hline Central Bank of India & 100 & 0 & 0 & 0 & 0 & 0 & 0 \\
\hline Corporation Bank & 57.2 & 29.4 & 10.2 & 0.5 & 0 & 2.7 & 0.2 \\
\hline Dena Bank & 51.2 & 2.9 & 0 & 7.2 & 0 & 31.1 & 7.6 \\
\hline Indian Bank & 100 & 0 & 0 & 0 & 0 & 0 & 0 \\
\hline Indian Overseas Bank & 61.2 & 6.9 & 8.9 & 2.6 & 0 & 19.2 & 1.2 \\
\hline Oriental Bank of Commerce & 66.5 & 11 & 14 & 1.5 & 0 & 7 & 0 \\
\hline Punjab \& Sind Bank & 100 & 0 & 0 & 0 & 0 & 0 & 0 \\
\hline Punjab National Bank & 57.8 & 6.4 & 18.3 & 3.3 & 0 & 14.1 & 0.1 \\
\hline Syndicate Bank & 73.5 & 5.3 & 2.7 & 1.6 & 0 & 16.7 & 0.2 \\
\hline UCO Bank & 75 & 5.8 & 0 & 3.3 & 1 & 14.8 & 0.2 \\
\hline Union Bank of India & 60.9 & 4.2 & 18.2 & 2.2 & 0 & 14.5 & 0.1 \\
\hline United Bank of India & 100 & 0 & 0 & 0 & 0 & 0 & 0 \\
\hline Vijaya Bank & 53.9 & 8 & 13.6 & 3.2 & 0 & 20.7 & 0.8 \\
\hline \multicolumn{8}{|l|}{ State Bank Group } \\
\hline State Bank of India & 59.7 & 11.4 & 19.8 & 2.6 & 0 & 6.4 & 0.1 \\
\hline $\begin{array}{l}\text { State Bank of Bikaner and } \\
\text { Jaipur }\end{array}$ & 0 & 76.4 & 0 & 6.2 & 4.5 & 12.8 & 0 \\
\hline State Bank of Hyderabad & 0 & $100 *$ & 0 & 0 & 0 & 0 & 0 \\
\hline State Bank of Indore & 0 & 98.1 & 0 & 0.7 & 0 & 1.3 & 0 \\
\hline State Bank of Mysore & 0 & 94 & 0 & 0.5 & 0.1 & 5.4 & 0 \\
\hline State Bank of Patiala & 0 & $100^{*}$ & 0 & 0 & 0 & 0 & 0 \\
\hline State Bank of Saurashtra & 0 & $100 *$ & 0 & 0 & 0 & 0 & 0 \\
\hline State Bank of Travancore & 1.1 & 77.7 & 2 & 2.7 & 0 & 12.4 & 4.1 \\
\hline
\end{tabular}

Note: Figures reported are percentages; RBI $=$ Reserve Bank of India; FIs $=$ Financial Institutions; $*$ for shares owned by the State Bank of India (and consequently considered by us as state-owned).

Source: RBI. 
Table 3: Share of banking assets held by bank groups, 1986-2003

This table shows the share of total assets held by each banking group in India during our period of analysis.

\begin{tabular}{rrrrr}
\hline \multicolumn{1}{l}{ Year } & \multicolumn{1}{c}{ Public } & Private & Foreign & New Private \\
\hline 1986 & 92.37 & 3.82 & 3.81 & - \\
1987 & 91.84 & 3.89 & 4.27 & - \\
1988 & 91.96 & 3.86 & 4.19 & - \\
1989 & 92.00 & 3.49 & 4.51 & - \\
1990 & 91.21 & 3.48 & 5.32 & - \\
1991 & 90.25 & 3.65 & 6.10 & - \\
1992 & 88.54 & 4.21 & 7.25 & - \\
1993 & 87.11 & 4.73 & 8.16 & - \\
1994 & 87.08 & 5.31 & 7.61 & - \\
1995 & 86.23 & 6.43 & 7.34 & - \\
1996 & 84.57 & 6.08 & 7.83 & 1.52 \\
1997 & 82.35 & 6.52 & 8.74 & 2.39 \\
1998 & 81.42 & 6.92 & 8.38 & 3.28 \\
1999 & 80.86 & 6.90 & 8.16 & 4.09 \\
2000 & 79.74 & 7.12 & 7.75 & 5.38 \\
2001 & 79.32 & 6.29 & 8.21 & 6.17 \\
2002 & 75.99 & 6.03 & 6.51 & 11.47 \\
2003 & 75.83 & 6.20 & 6.75 & 11.21 \\
\hline
\end{tabular}

Note: - for new private banks prior to their entry (new private banks are those that started operations in 1996); figures reported are percentages.

Source: RBI. 


\section{Table 4: Descriptive Statistics}

This table presents the descriptive statistics for the five performance indicators and the control variables used in the regression models.

\begin{tabular}{|c|c|c|c|c|c|}
\hline Bank Characteristics & Mean & Std. Dev. & Median & Maximum & Minimum \\
\hline \multicolumn{6}{|l|}{$\log (T F P)$} \\
\hline Public banks & 4.86 & 0.25 & 4.78 & 5.68 & 4.57 \\
\hline PP banks & 4.87 & 0.25 & 4.79 & 5.63 & 4.59 \\
\hline Never PP banks & 4.86 & 0.26 & 4.78 & 5.68 & 4.57 \\
\hline Private banks & 4.76 & 0.19 & 4.70 & 5.51 & 4.51 \\
\hline \multicolumn{6}{|l|}{ Operating profit ratio } \\
\hline Public banks & 0.09 & 1.17 & 0.20 & 1.76 & -8.02 \\
\hline PP banks & 0.26 & 0.97 & 0.26 & 1.63 & -6.67 \\
\hline Never PP banks & -0.10 & 1.35 & 0.15 & 1.76 & -8.02 \\
\hline Private banks & 0.46 & 1.22 & 0.44 & 16.37 & -8.51 \\
\hline \multicolumn{6}{|l|}{ Net interest margin } \\
\hline Public banks & 2.52 & 0.81 & 2.60 & 5.73 & -4.45 \\
\hline PP banks & 2.53 & 0.77 & 2.62 & 4.73 & -4.45 \\
\hline Never PP banks & 2.51 & 0.86 & 2.52 & 5.73 & 0.48 \\
\hline Private banks & 2.80 & 1.87 & 2.74 & 35.31 & -6.90 \\
\hline \multicolumn{6}{|l|}{ Operating cost ratio } \\
\hline Public banks & 2.68 & 0.48 & 2.66 & 4.36 & 1.41 \\
\hline PP banks & 2.60 & 0.49 & 2.57 & 3.77 & 1.41 \\
\hline Never PP banks & 2.77 & 0.45 & 2.72 & 4.36 & 1.73 \\
\hline Private banks & 3.07 & 3.69 & 2.80 & 72.82 & 0.00 \\
\hline \multicolumn{6}{|l|}{ Staff expense ratio } \\
\hline Public banks & 1.97 & 1.13 & 1.92 & 23.65 & 0.85 \\
\hline PP banks & 1.83 & 0.42 & 1.81 & 3.03 & 0.85 \\
\hline Never PP banks & 2.13 & 1.59 & 2.01 & 23.65 & 1.17 \\
\hline Private banks & 1.99 & 0.93 & 1.93 & 11.23 & 0.30 \\
\hline \multicolumn{6}{|l|}{ Proportion of Rural Branches (\%) } \\
\hline Public banks & 66.53 & 5.78 & 67.29 & 80.81 & 46.35 \\
\hline PP banks & 66.61 & 6.87 & 67.53 & 80.81 & 46.35 \\
\hline Never PP banks & 66.43 & 4.15 & 66.62 & 76.47 & 55.61 \\
\hline Private banks & 59.59 & 16.92 & 63.30 & 84.38 & 0.00 \\
\hline \multicolumn{6}{|l|}{ Proportion of Non-interest } \\
\hline Public banks & 11.38 & 5.49 & 11.12 & 94.70 & 4.60 \\
\hline PP banks & 11.29 & 6.64 & 10.93 & 94.70 & 4.61 \\
\hline Never PP banks & 11.50 & 3.71 & 11.22 & 23.64 & 4.60 \\
\hline Private banks & 10.48 & 34.83 & 11.38 & 34.32 & 2.94 \\
\hline \multicolumn{6}{|l|}{ Size } \\
\hline Public banks & 9.90 & 10.57 & 9.17 & 12.84 & 6.40 \\
\hline PP banks & 10.23 & 10.83 & 9.42 & 12.84 & 6.89 \\
\hline Never PP banks & 9.26 & 9.19 & 8.92 & 10.95 & 6.40 \\
\hline Private banks & 7.46 & 7.81 & 6.56 & 9.73 & 1.92 \\
\hline
\end{tabular}

Note: Size is natural logarithm of total assets (at 1993-94 prices). PP refers to partially privatized. 
Table 5: Correlation matrix of independent variables

This table presents the pair-wise correlation coefficients for all the independent variables used in the regression models.

\begin{tabular}{|l|r|r|r|r|r|r|r|}
\hline & PRIV_SHARE & LIST_TREND & LIST_DUM & PRIV_SECTOR & PROP_RUR & PROP_NINT & SIZE \\
\hline PRIV_SHARE & 1 & & & & & & \\
\hline LIST_TREND & 0.7881 & 1 & & & & & \\
\hline LIST_DUM & 0.9820 & 0.7613 & 1 & & & & \\
\hline PRIV_SECTOR & -0.2946 & -0.2284 & -0.3000 & 1 & & & \\
\hline PROP_RUR & 0.0177 & 0.0165 & 0.0292 & -0.2674 & 1 & & \\
\hline PROP_NINT & 0.0053 & 0.0041 & 0.0054 & -0.0193 & -0.0557 & 1 & \\
\hline SIZE & 0.3866 & 0.3318 & 0.3805 & -0.7632 & 0.2753 & 0.0221 & 1 \\
\hline
\end{tabular}


Table 6: Partial Privatization and Bank Performance: Roles of listing trend and ownership share

The five performance indicators are regressed on the percentage of shares held by the private owners (PRIV_SHARE) and a variable that operates as a trend once a bank is listed (LIST_TREND). PRIV_SECTOR is a dummy variable for banks in the private sector. Panel regression technique (within effects) is employed to estimate the model.

\begin{tabular}{|c|c|c|c|c|c|}
\hline & $\log ($ TFP) & OPR & NIM & OCR & SER \\
\hline PRIV_SHARE & $\begin{array}{l}0.0007^{\star} \\
(0.0004)\end{array}$ & $\begin{array}{l}0.0218^{\star \star \star} \\
(0.0037)\end{array}$ & $\begin{array}{l}0.0194^{\star \star \star} \\
(0.0036)\end{array}$ & $\begin{array}{l}-0.0030 \\
(0.0082)\end{array}$ & $\begin{array}{l}-0.0001 \\
(0.0045)\end{array}$ \\
\hline LIST_TREND & $\begin{array}{l}0.0220^{\star * *} \\
(0.0021)\end{array}$ & $\begin{array}{l}-0.0862 \\
(0.0554)\end{array}$ & $\begin{array}{l}-0.0258 \\
(0.0159)\end{array}$ & $\begin{array}{l}0.0107 \\
(0.0185)\end{array}$ & $\begin{array}{l}-0.0057 \\
(0.01252)\end{array}$ \\
\hline PRIV_SECTOR & $\begin{array}{l}-0.1008^{* * *} \\
(0.0171)\end{array}$ & $\begin{array}{l}0.6460^{\star \star \star} \\
(0.1799)\end{array}$ & $\begin{array}{l}-0.3569^{\star \star} \\
(0.1706)\end{array}$ & $\begin{array}{l}-0.0796 \\
(0.5152)\end{array}$ & $\begin{array}{l}-0.5722^{\star \star \star} \\
(0.0890)\end{array}$ \\
\hline PROP_RUR & $\begin{array}{l}0.1000^{* *} \\
(0.0410)\end{array}$ & $\begin{array}{l}0.6713 \\
(0.5117)\end{array}$ & $\begin{array}{l}1.7970^{* * *} \\
(0.2085)\end{array}$ & $\begin{array}{l}1.1983^{* *} \\
(0.5630)\end{array}$ & $\begin{array}{l}1.7585^{\star * *} \\
(0.2480)\end{array}$ \\
\hline PROP_NINT & $\begin{array}{l}0.0000 \\
(<0.0001)\end{array}$ & $\begin{array}{l}0.0009^{\star *} \\
(0.0003)\end{array}$ & $\begin{array}{l}-0.0022^{\star \star \star} \\
(0.0003)\end{array}$ & $\begin{array}{l}-0.0036^{\star \star \star} \\
(0.0003)\end{array}$ & $\begin{array}{l}-0.0036^{* * *} \\
(0.0003)\end{array}$ \\
\hline SIZE & $\begin{array}{l}-0.0135^{\star \star \star} \\
(0.0040)\end{array}$ & $\begin{array}{l}0.0595 \\
(0.0455)\end{array}$ & $\begin{array}{l}-0.3309^{* * *} \\
(0.0670)\end{array}$ & $\begin{array}{l}-0.2086 \\
(0.1749)\end{array}$ & $\begin{array}{l}-0.2732^{* * *} \\
(0.0305)\end{array}$ \\
\hline INTERCEPT & $\begin{array}{l}4.8401^{\star * *} \\
(0.0211)\end{array}$ & $\begin{array}{l}-0.7239^{*} \\
(0.3721)\end{array}$ & $\begin{array}{l}2.7741^{\star * \star} \\
(0.2224)\end{array}$ & $\begin{array}{l}2.8585^{\star \star \star} \\
(0.5050)\end{array}$ & $\begin{array}{l}2.0677^{\star \star \star} \\
(0.1154)\end{array}$ \\
\hline R-square & 0.1994 & 0.0510 & 0.0824 & 0.0140 & 0.1009 \\
\hline No. of obs. & 828 & 841 & 841 & 841 & 841 \\
\hline
\end{tabular}

Note: Numbers in parentheses are robust standard errors (Huber-White). ${ }^{* * *}, * *$ and $*$ indicate statistically significant coefficients at the levels of $1 \%, 5 \%$ and $10 \%$ respectively. 
Table 7: Partial Privatization and Bank Performance: Roles of listing effect and ownership share

The five performance indicators are regressed on the percentage of shares held by the private owners (PRIV_SHARE) and a dummy variable that indicates whether a bank is listed or not (LIST_DUM). PRIV_SECTOR is a dummy variable for banks in the private sector. Panel regression technique (within effects) is employed to estimate the model.

\begin{tabular}{|c|c|c|c|c|c|}
\hline & $\log ($ TFP) & OPR & NIM & OCR & SER \\
\hline PRIV_SHARE & $\begin{array}{l}-0.0024 \\
(0.0016)\end{array}$ & $\begin{array}{l}0.0258^{\star \star \star} \\
(0.0059)\end{array}$ & $\begin{array}{l}0.0220^{*} \\
(0.0107)\end{array}$ & $\begin{array}{l}-0.0234 \\
(0.0176)\end{array}$ & $\begin{array}{l}-0.0139^{* *} \\
(0.0049)\end{array}$ \\
\hline LIST_DUM & $\begin{array}{l}0.1663^{\star * *} \\
(0.0253)\end{array}$ & $\begin{array}{l}-0.3765 \\
(0.2246)\end{array}$ & $\begin{array}{l}-0.1573 \\
(0.4120)\end{array}$ & $\begin{array}{l}0.7059^{*} \\
(0.3731)\end{array}$ & $\begin{array}{l}0.4413 \\
(0.2693)\end{array}$ \\
\hline PRIV_SECTOR & $\begin{array}{l}-0.0948^{\star * *} \\
(0.0160)\end{array}$ & $\begin{array}{l}0.6302^{* * \star} \\
(0.1857)\end{array}$ & $\begin{array}{l}-0.3625^{\star} \\
(0.1779)\end{array}$ & $\begin{array}{l}-0.0637 \\
(0.5246)\end{array}$ & $\begin{array}{l}-0.5634^{\star \star \star} \\
(0.0900)\end{array}$ \\
\hline PROP_RUR & $\begin{array}{l}0.0937^{* *} \\
(0.0404)\end{array}$ & $\begin{array}{l}0.6794 \\
(0.5160)\end{array}$ & $\begin{array}{l}1.8014^{* * *} \\
(0.2185)\end{array}$ & $\begin{array}{l}1.1689^{*} \\
(0.5769)\end{array}$ & $\begin{array}{l}1.7390^{\star * *} \\
(0.2492)\end{array}$ \\
\hline PROP_NINT & $\begin{array}{l}0.0000 \\
(<0.0001)\end{array}$ & $\begin{array}{l}0.0009^{* *} \\
(0.0003)\end{array}$ & $\begin{array}{l}-0.0022^{* \star *} \\
(0.0003)\end{array}$ & $\begin{array}{l}-0.0037^{\star * *} \\
(0.0003)\end{array}$ & $\begin{array}{l}-0.0036^{\star \star \star} \\
(0.0003)\end{array}$ \\
\hline SIZE & $\begin{array}{l}-0.0115^{\star *} \\
(0.0041)\end{array}$ & $\begin{array}{l}0.0542 \\
(0.0480)\end{array}$ & $\begin{array}{l}-0.3328^{* * *} \\
(0.0696)\end{array}$ & $\begin{array}{l}-0.2037 \\
(0.1780)\end{array}$ & $\begin{array}{l}-0.2704^{\star * *} \\
(0.0312)\end{array}$ \\
\hline INTERCEPT & $\begin{array}{l}4.8341^{\star * *} \\
(0.0236)\end{array}$ & $\begin{array}{l}-0.7031^{*} \\
(0.3734)\end{array}$ & $\begin{array}{l}2.7809^{* * *} \\
(0.2265)\end{array}$ & $\begin{array}{l}2.8503^{* \star *} \\
(0.5111)\end{array}$ & $\begin{array}{l}2.0652^{\star \star \star} \\
(0.1138)\end{array}$ \\
\hline R-square & 0.1912 & 0.0491 & 0.0823 & 0.0142 & 0.1014 \\
\hline No. of obs. & 828 & 841 & 841 & 841 & 841 \\
\hline
\end{tabular}

Note: Numbers in parentheses are robust standard errors (Huber-White). $* * *, * *$ and $*$ indicate statistically significant coefficients at the levels of $1 \%, 5 \%$ and $10 \%$ respectively. 
Table 8: Partial Privatization and Bank Performance (Only Partially Privatized Banks): Roles of listing trend and ownership share

The five performance indicators are regressed on the percentage of shares held by the private owners (PRIV_SHARE) and a variable that operates as a trend once a bank is listed (LIST_TREND). The sample for this estimation consists of only those banks that went on to be partially privatized. Panel regression technique (within effects) is employed to estimate the model.

\begin{tabular}{|c|c|c|c|c|c|}
\hline & $\log ($ TFP) & OPR & NIM & OCR & SER \\
\hline PRIV_SHARE & $\begin{array}{l}0.0002 \\
(0.0004)\end{array}$ & $\begin{array}{l}0.0179^{\star * \star} \\
(0.0031)\end{array}$ & $\begin{array}{l}0.0095^{\star *} \\
(0.0039)\end{array}$ & $\begin{array}{l}-0.0070^{\star \star} \\
(0.0026)\end{array}$ & $\begin{array}{l}-0.0091^{* * *} \\
(0.0020)\end{array}$ \\
\hline LIST_TREND & $\begin{array}{l}0.0194^{\star \star *} \\
(0.0020)\end{array}$ & $\begin{array}{l}-0.0529 \\
(0.0444)\end{array}$ & $\begin{array}{l}-0.0254 \\
(0.0182)\end{array}$ & $\begin{array}{l}-0.0392^{\star \star} \\
(0.0160)\end{array}$ & $\begin{array}{l}-0.0473^{* \star *} \\
(0.0129)\end{array}$ \\
\hline PROP_RUR & $\begin{array}{l}0.6259^{\star * *} \\
(0.0854)\end{array}$ & $\begin{array}{l}0.0424 \\
(0.5688)\end{array}$ & $\begin{array}{l}-0.0534 \\
(0.2862)\end{array}$ & $\begin{array}{l}0.9968^{* * *} \\
(0.2243)\end{array}$ & $\begin{array}{l}1.3426^{* * *} \\
(0.1750)\end{array}$ \\
\hline PROP_NINT & $\begin{array}{l}0.0138 \\
(0.0236)\end{array}$ & $\begin{array}{l}-0.0547 \\
(0.1423)\end{array}$ & $\begin{array}{l}-7.9421^{\star \star \star} \\
(0.4668)\end{array}$ & $\begin{array}{l}0.9449^{* \star *} \\
(0.3188)\end{array}$ & $\begin{array}{l}0.8475^{\star \star *} \\
(0.2383)\end{array}$ \\
\hline SIZE & $\begin{array}{l}-0.0154^{\star * *} \\
(0.0041)\end{array}$ & $\begin{array}{l}-0.0250 \\
(0.0206)\end{array}$ & $\begin{array}{l}-0.2463^{\star * \star} \\
(0.0560)\end{array}$ & $\begin{array}{l}-0.1643^{\star \star \star} \\
(0.0425)\end{array}$ & $\begin{array}{l}-0.1052^{* \star \star} \\
(0.0327)\end{array}$ \\
\hline INTERCEPT & $\begin{array}{l}4.5090^{\star \star *} \\
(0.0391)\end{array}$ & $\begin{array}{l}0.2298 \\
(0.3890)\end{array}$ & $\begin{array}{l}3.6484^{\star \star \star} \\
(0.2449)\end{array}$ & $\begin{array}{l}2.8696^{\star \star *} \\
(0.2433)\end{array}$ & $\begin{array}{l}1.6085^{\star \star \star} \\
(0.2009)\end{array}$ \\
\hline R-square & 0.4266 & 0.0365 & 0.4797 & 0.2083 & 0.2143 \\
\hline No. of obs. & 234 & 234 & 234 & 234 & 234 \\
\hline
\end{tabular}

Note: Numbers in parentheses are robust standard errors (Huber-White). ${ }^{* *},{ }^{*} *$ and $*$ indicate statistically significant coefficients at the levels of $1 \%, 5 \%$ and $10 \%$ respectively. 
Table 9: Partial Privatization and Bank Performance (Only Partially Privatized Banks): Roles of listing effect and ownership share

The five performance indicators are regressed on the percentage of shares held by the private owners (PRIV_SHARE) and a dummy variable that indicates whether a bank is listed or not (LIST_DUM). The sample for this estimation consists of only those banks that went on to be partially privatized. Panel regression technique (within effects) is employed to estimate the model.

\begin{tabular}{|c|c|c|c|c|c|}
\hline & $\log ($ TFP) & OPR & NIM & OCR & SER \\
\hline PRIV_SHARE & $\begin{array}{l}0.0007 \\
(0.0008)\end{array}$ & $\begin{array}{l}0.0275^{\star \star \star} \\
(0.0054)\end{array}$ & $\begin{array}{l}0.0024 \\
(0.0087)\end{array}$ & $\begin{array}{l}-0.0239^{\star \star \star} \\
(0.0067)\end{array}$ & $\begin{array}{l}-0.0298^{\star \star \star} \\
(0.0059)\end{array}$ \\
\hline LIST_DUM & $\begin{array}{l}0.0247 \\
(0.0321)\end{array}$ & $\begin{array}{l}-0.4513 \\
(0.3003)\end{array}$ & $\begin{array}{l}0.2008 \\
(0.3027)\end{array}$ & $\begin{array}{l}0.5230 \\
(0.4214)\end{array}$ & $\begin{array}{l}0.6432 \\
(0.3984)\end{array}$ \\
\hline PROP_RUR & $\begin{array}{l}0.6189^{\star * *} \\
(0.0977)\end{array}$ & $\begin{array}{l}0.2879 \\
(0.6229)\end{array}$ & $\begin{array}{l}-0.1816 \\
(0.3969)\end{array}$ & $\begin{array}{l}0.6733^{\star *} \\
(0.2683)\end{array}$ & $\begin{array}{l}0.9452^{\star \star *} \\
(0.2091)\end{array}$ \\
\hline PROP_NINT & $\begin{array}{l}0.0329^{\star *} \\
(0.0125)\end{array}$ & $\begin{array}{l}-0.1279 \\
(0.1030)\end{array}$ & $\begin{array}{l}-7.9544^{* * *} \\
(0.4629)\end{array}$ & $\begin{array}{l}0.9376^{\star \star \star} \\
(0.3279)\end{array}$ & $\begin{array}{l}0.8394^{\star * *} \\
(0.2495)\end{array}$ \\
\hline SIZE & $\begin{array}{l}-0.0103^{\star \star *} \\
(0.0035)\end{array}$ & $\begin{array}{l}-0.0527^{\star * \star} \\
(0.0189)\end{array}$ & $\begin{array}{l}-0.2447^{\star \star \star} \\
(0.0592)\end{array}$ & $\begin{array}{l}-0.1542^{\star \star *} \\
(0.0470)\end{array}$ & $\begin{array}{l}-0.0926^{* *} \\
(0.0373)\end{array}$ \\
\hline INTERCEPT & $\begin{array}{l}4.4942^{* \star *} \\
(0.0499)\end{array}$ & $\begin{array}{l}0.1976 \\
(0.4014)\end{array}$ & $\begin{array}{l}3.7121^{* * *} \\
(0.2282)\end{array}$ & $\begin{array}{l}3.0014^{\star * \star} \\
(0.2103)\end{array}$ & $\begin{array}{l}1.7705^{\star \star \star} \\
(0.1679)\end{array}$ \\
\hline R-square & 0.3413 & 0.0342 & 0.4773 & 0.2104 & 0.2186 \\
\hline No. of obs. & 234 & 234 & 234 & 234 & 234 \\
\hline
\end{tabular}

Note: Numbers in parentheses are robust standard errors (Huber-White). ${ }^{* *},{ }^{*} *$ and $*$ indicate statistically significant coefficients at the levels of $1 \%, 5 \%$ and $10 \%$ respectively. 


\section{Appendix A}

Following Kumbhakar and Lovell (2000), the Divisia index of TFP growth for multiple outputs can be written as:

$$
T F \dot{P}=\dot{Y}-\dot{X}=\sum_{m} R_{m} \dot{y}_{m}-\sum_{j} S_{j} \dot{x}_{j}
$$

where, $R_{m}=p_{m} y_{m} / R$ is the observed revenue share of output $y_{m}, p_{m}$ is the price of output $y_{m}$, and $R=\Sigma_{m} p_{m} y_{m}$ is total revenue. Likewse, $S_{j}=w_{j} x_{j} / C$ is the observed cost share of input $x_{j}, \mathrm{w}_{j}$ is the price of input $\mathrm{x}_{j}$, and $C=\Sigma_{j} w_{j} x_{j}$ is total cost. Here a ' ' over a variable indicates its growth rate, i.e., $\dot{x}_{j}=\frac{\partial \ln x_{j}}{\partial t}$.

Equation (A.1) is hard to estimate especially in the case of banks due to unavailability of price information and so it needs to be transformed into an estimable form. Consequently we consider the following stochastic cost frontier:

$$
\ln E=\ln C(Y, W, t)+U+\mathrm{V}
$$

where, $E=W X$ is total expenditure, $X=\left(x_{1}, \ldots, x_{N}\right)^{\prime}$ is a $(\mathrm{N} \mathrm{x} 1)$ vector of inputs, $W=$ $\left(w_{1}, \ldots, w_{N}\right)$, is a $(\mathrm{N} \times 1)$ vector of input prices, $Y=\left(y_{1}, \ldots, y_{M}\right)^{\prime}$ is a $(\mathrm{M} \mathrm{x} 1)$ vector of outputs, $t$ is a time trend that proxies technical change, $C(Y, W, t)$ is the deterministic kernel of the stochastic cost frontier, $U \geq 0$ is the one-sided cost inefficiency term, and $\mathrm{V}$ is a random variable with zero mean.

Totally differentiating equation (A.2), we obtain the following expression:

$$
\dot{E}=\varepsilon(Y, W, t) \sum_{m} R_{m} \dot{y}_{m}+\sum_{n} S_{n} \dot{w}_{n}+\dot{C}(Y, W, t)+\frac{\partial U}{\partial t}
$$

Solving this for $\sum_{m} R_{m} \dot{y}_{m}$, substituting it in (A.1) and using the fact that $\dot{E}-\sum_{n}\left(w_{n} x_{n} / E\right) \dot{x}_{n}=\sum_{n}\left(w_{n} x_{n} / E\right) \dot{w}_{n}$, leads to the following expression: 
$T \dot{F} P=-\dot{C}(Y, W, t)+[1-\varepsilon(Y, W, t)] \dot{Y}^{C}-\sum_{n}\left[S_{n}-S_{n}(Y, W, t)\right] \dot{w}_{n}+\left(Y-\dot{Y}^{C}\right)-\frac{\partial U}{\partial t}$

where $\dot{Y}=\sum_{m} \frac{\varepsilon_{m}(Y, W, t)}{\varepsilon(Y, W, t)}$ is a measure of output growth, $\varepsilon_{m}(Y, W, t)$ is cost elasticity of the $\mathrm{m}^{\text {th }}$ output and $\varepsilon(Y, W, t)=\sum_{m} \varepsilon_{m}(Y, W, t)$. Here $\left(\dot{y}-\dot{y}^{C}\right)$ captures the impact on productivity change of departures from marginal cost pricing and along with $\sum_{n}\left[S_{n}-S_{n}(Y, W, t)\right] \dot{w}_{n}$, gives a measure of input allocative efficiency change. Assuming allocative efficiency yields the following estimable expression for TFP growth:

$$
T F \dot{P}=-\dot{C}(Y, W, t)+[1-\varepsilon(Y, W, t)] \dot{Y}^{c}-\frac{\partial U}{\partial t}
$$

Defining returns to scale as the inverse of $\varepsilon(Y, W, t)$, expression (A.3) provides a decomposition of TFP into the following components: contribution of technical change measured by cost diminution $(-\dot{C}(Y, W, t))$, contribution of scale effect $\left([1-\varepsilon(Y, W, t)] \dot{Y}^{c}\right)$, and contribution of efficiency $\left(-\frac{\partial U}{\partial t}\right)$. Denoting these three components by $T F \dot{P}_{1}, T F \dot{P}_{2}$ and $T F \dot{P}_{3}$ respectively, we can define TFP growth as a sum of its three components:

$T F \dot{P}=T F \dot{P}_{1}+T F \dot{P}_{2}+T F \dot{P}_{3}$ 


\section{Appendix B}

\section{Table B.1: Description of Variables}

This table defines all the variables used in this study.

\begin{tabular}{|c|c|}
\hline List of variables & Definition \\
\hline \multicolumn{2}{|c|}{ Variables used in estimating total factor productivity } \\
\hline \multicolumn{2}{|c|}{ (These are obtained from balance sheets and hence indicate end-year balances) } \\
\hline Fixed deposit & Term deposit \\
\hline Savings deposit & Interest bearing checkable deposit \\
\hline Current deposit & Non-interest bearing checkable deposit \\
\hline Loans & $\begin{array}{l}\text { Loans and advances including bills, cash credit, overdrafts and } \\
\text { term loans }\end{array}$ \\
\hline Investments & Investments in shares, bonds and other instruments \\
\hline Branches & Number of branches - domestic and international \\
\hline Labor & Number of employees - officers, staff and clerical \\
\hline Capital & Value of fixed assets such as premises \\
\hline Price of labor & $\begin{array}{l}\text { Ratio of establishment expenses to total employees where } \\
\text { establishment expenses refer to payments to and provisions } \\
\text { for employees }\end{array}$ \\
\hline Price of capital & $\begin{array}{l}\text { Ratio of capital expenses to fixed assets where capital } \\
\text { expenses refer to expenses on physical capital e.g. rent, taxes, } \\
\text { lighting, insurance, depreciation, repairs and maintenance }\end{array}$ \\
\hline \multicolumn{2}{|c|}{ Variables used as accounting indicators of performance } \\
\hline \multicolumn{2}{|c|}{$\begin{array}{l}\text { (These are obtained from profit and loss accounts and hence indicate transactions during the year } \\
\text { recorded at end-year) }\end{array}$} \\
\hline Operating Profit Ratio & Ratio of operating profit to total assets \\
\hline Net Interest Margin & Ratio of interest income minus interest expense to total assets \\
\hline Operating Cost Ratio & $\begin{array}{l}\text { Ratio of operating expenses (on labor and capital) to total } \\
\text { expenses }\end{array}$ \\
\hline Staff Expense Ratio & $\begin{array}{l}\text { Ratio of payments and provisions to employees to total } \\
\text { expenses }\end{array}$ \\
\hline \multicolumn{2}{|c|}{ Variables used as determinants of productivity and performance } \\
\hline \multicolumn{2}{|c|}{ (These are obtained from balance sheets and hence indicate end-year balances) } \\
\hline Size & Logarithm of total assets \\
\hline Proportion of rural branches & Ratio of number of rural branches to total number of branches \\
\hline Proportion of non-interest income & $\begin{array}{l}\text { Ratio of income from non-interest bearing activities (e.g. } \\
\text { commission, exchange, brokerage, revaluation, sale of } \\
\text { investments and assets) to total income }\end{array}$ \\
\hline \multicolumn{2}{|l|}{ Variables capturing privatization } \\
\hline PRIV_SHARE & The percentage of shares held by private owners \\
\hline LIST_TREND & $\begin{array}{l}\text { A trend variable that operates once a bank is listed (i.e. takes } \\
\text { the value } 0 \text { in all years prior to listing and } 1,2,3 \text { etc. after listing) }\end{array}$ \\
\hline LIST_DUM & A dummy variable that indicates whether a bank is listed or not \\
\hline PRIV_SECTOR & A dummy variable for banks in the private sector \\
\hline
\end{tabular}


Table B.2: Performance Comparisons of Non-Privatized Banks and Partially Privatized (PP) Banks But Considered Only Before the Listing Year

This table presents statistical tests of differences between public banks that were never privatized and those that went on to be partially privatized based on the five performance indicators.

\begin{tabular}{|c|c|c|c|c|}
\hline & $\begin{array}{l}\text { Mean of never PP } \\
\text { banks } \\
\text { (Median of never PP } \\
\text { banks) }\end{array}$ & $\begin{array}{l}\text { Mean of PP banks } \\
\text { (Median of PP } \\
\text { banks) }\end{array}$ & $\begin{array}{l}\text { t-stats for } \\
\text { difference } \\
\text { in mean } \\
(p \text {-value })\end{array}$ & $\begin{array}{l}\text { Wilcoxon }-\mathrm{Z} \\
\text { for difference in } \\
\text { Median } \\
\text { (p-value) }\end{array}$ \\
\hline $\log (\mathrm{TFP})$ & $\begin{array}{l}4.8607 \\
(4.7786)\end{array}$ & $\begin{array}{l}.7316 \\
(4.6978)\end{array}$ & $\begin{array}{l}5.72 \\
(<0.0001)\end{array}$ & $\begin{array}{l}-3.0257 \\
(0.0012)\end{array}$ \\
\hline OPR & $\begin{array}{l}-0.1025 \\
(0.1500)\end{array}$ & $\begin{array}{l}0.0036 \\
(0.1700)\end{array}$ & $\begin{array}{l}-0.82 \\
(0.4127)\end{array}$ & $\begin{array}{l}1.1638 \\
(0.1222)\end{array}$ \\
\hline NIM & $\begin{array}{l}2.5113 \\
(2.5250)\end{array}$ & $\begin{array}{l}2.3689 \\
(2.4200)\end{array}$ & $\begin{array}{l}1.58 \\
(0.1148)\end{array}$ & $\begin{array}{l}-1.1182 \\
(0.1317)\end{array}$ \\
\hline OCR & $\begin{array}{l}2.7724 \\
(2.7250)\end{array}$ & $\begin{array}{l}2.7068 \\
(2.7200)\end{array}$ & $\begin{array}{l}1.34 \\
(0.1804)\end{array}$ & $\begin{array}{l}-0.1864 \\
(0.4260)\end{array}$ \\
\hline SER & $\begin{array}{l}2.1344 \\
(2.0150)\end{array}$ & $\begin{array}{l}1.9052 \\
(1.9100)\end{array}$ & $\begin{array}{l}1.79 \\
(0.0743)\end{array}$ & $\begin{array}{l}-2.8254 \\
(0.0024)\end{array}$ \\
\hline
\end{tabular}


Table B.3: Partial Privatization and Bank Performance: Instrumental Variables (1987-2003)

The five performance indicators are regressed on the percentage of shares held by the private owners (PRIV_SHARE) - which for each regression is instrumented using lags of other performance indicators, fiscal deficit and stock market index. Panel regression technique (within effects) is employed to estimate the model.

\begin{tabular}{|c|c|c|c|c|c|}
\hline & Log (TFP) & OPR & NIM & OCR & SER \\
\hline PRIV_SHARE & $\begin{array}{l}-0.0010 \\
(0.0025)\end{array}$ & $\begin{array}{l}0.1145^{\star \star \star} \\
(0.0377)\end{array}$ & $\begin{array}{l}0.0940 \\
(0.0823)\end{array}$ & $\begin{array}{l}-0.2318 \\
(0.1504)\end{array}$ & $\begin{array}{l}-0.1291^{\star \star \star} \\
(0.0409)\end{array}$ \\
\hline PRIV_SECTOR & $\begin{array}{l}-0.1026^{\star \star \star} \\
(0.0187)\end{array}$ & $\begin{array}{l}0.6893^{\star \star \star} \\
(0.1991)\end{array}$ & $\begin{array}{l}-0.4645^{\star} \\
(0.2383)\end{array}$ & $\begin{array}{l}-0.2925 \\
(0.4267)\end{array}$ & $\begin{array}{l}-0.7265^{\star \star \star} \\
(0.1114)\end{array}$ \\
\hline PROP_RUR & $\begin{array}{l}0.0843^{*} \\
(0.0447)\end{array}$ & $\begin{array}{l}0.5884 \\
(0.5578)\end{array}$ & $\begin{array}{l}1.5194^{\star \star \star} \\
(0.2006)\end{array}$ & $\begin{array}{l}1.3300^{\star *} \\
(0.5364)\end{array}$ & $\begin{array}{l}1.6664^{\star \star \star} \\
(0.2491)\end{array}$ \\
\hline PROP_NINT & $\begin{array}{l}-0.0001 \\
(<0.0001)\end{array}$ & $\begin{array}{l}0.0007^{*} \\
(0.0003)\end{array}$ & $\begin{array}{l}-0.0022^{* \star *} \\
(0.0004)\end{array}$ & $\begin{array}{l}-0.0035^{\star \star \star *} \\
(0.0003)\end{array}$ & $\begin{array}{l}-0.0034^{\star \star \star} \\
(0.0002)\end{array}$ \\
\hline SIZE & $\begin{array}{l}-0.0087^{* *} \\
(0.0039)\end{array}$ & $\begin{array}{l}0.0553 \\
(0.0517)\end{array}$ & $\begin{array}{l}-0.3897^{* * *} \\
(0.0970)\end{array}$ & $\begin{array}{l}-0.2268 \\
(0.1693)\end{array}$ & $\begin{array}{l}-0.3162^{\star * \star} \\
(0.0223)\end{array}$ \\
\hline INTERCEPT & $\begin{array}{l}4.8466^{\star \star \star} \\
(0.0261)\end{array}$ & $\begin{array}{l}-0.9526^{*} \\
(0.4505)\end{array}$ & $\begin{array}{l}3.0312^{* \star *} \\
(0.6644)\end{array}$ & $\begin{array}{l}3.5851^{* * *} \\
(0.2545)\end{array}$ & $\begin{array}{l}2.7447^{* * *} \\
(0.1401)\end{array}$ \\
\hline R-square & 0.1509 & 0.0624 & 0.0874 & 0.0307 & 0.1332 \\
\hline No. of obs. & 821 & 821 & 821 & 821 & 821 \\
\hline
\end{tabular}

Note: Instrument validity was ascertained by checking that the instruments are highly correlated with PRIV_SHARE but weakly correlated with the residuals. Numbers in parentheses are robust standard errors (Huber-White). $* * *, * *$ and $*$ indicate statistically significant coefficients at the levels of $1 \%, 5 \%$ and $10 \%$ respectively. 
Table B.4: Partial Privatization and Bank Performance: Instrumental Variables with 2 stage estimation (1987-2003)

The five performance indicators are regressed on the percentage of shares held by the private owners (PRIV_SHARE) - which for each regression is instrumented using lags of other performance indicators, fiscal deficit and the BSE index. A two-stage estimation procedure is used for the instrumental variable by modeling the privatization decision in the first stage and the quantum of privatization in the second stage. Panel regression technique (within effects) is employed to estimate the model.

\begin{tabular}{|c|c|c|c|c|c|}
\hline & $\log ($ TFP) & OPR & $\mathrm{NIM}$ & OCR & $\begin{array}{l}\text { SER } \\
\end{array}$ \\
\hline PRIV_SHARE & $\begin{array}{l}.0048 \\
(0.0047)\end{array}$ & $\begin{array}{l}0.0620^{\star * *} \\
(0.0214)\end{array}$ & $\begin{array}{l}0.0771^{*} \\
(0.0450)\end{array}$ & $\begin{array}{l}-0.1376 \\
(0.0928)\end{array}$ & $\begin{array}{l}-0.0482^{*} \\
(0.0248)\end{array}$ \\
\hline PRIV_SECTOR & $\begin{array}{l}-0.0047^{* * *} \\
(0.0207)\end{array}$ & $\begin{array}{l}0.7105^{\star * \star} \\
(0.2096)\end{array}$ & $\begin{array}{l}-0.3782^{*} \\
(0.2022)\end{array}$ & $\begin{array}{l}-0.2673 \\
(0.4632)\end{array}$ & $\begin{array}{l}-0.6779^{* \star \star} \\
(0.1121)\end{array}$ \\
\hline PROP_RUR & $\begin{array}{l}0.0994^{*} \\
(0.0486)\end{array}$ & $\begin{array}{l}0.6407 \\
(0.5815)\end{array}$ & $\begin{array}{l}1.7649^{* * *} \\
(0.2781)\end{array}$ & $\begin{array}{l}1.3615^{\star *} \\
(0.5277)\end{array}$ & $\begin{array}{l}1.8629^{* * *} \\
(0.2911)\end{array}$ \\
\hline PROP_NINT & $\begin{array}{l}-0.0001^{*} \\
(<0.0001)\end{array}$ & $\begin{array}{l}0.0007^{*} \\
(0.0003)\end{array}$ & $\begin{array}{l}-0.0023^{\star \star \star} \\
(0.0003)\end{array}$ & $\begin{array}{l}-0.0035^{\star \star \star \star} \\
(0.0003)\end{array}$ & $\begin{array}{l}-0.0035^{\star \star *} \\
(0.0003)\end{array}$ \\
\hline SIZE & $\begin{array}{l}-0.0108^{\star *} \\
(0.0040)\end{array}$ & $\begin{array}{l}0.0634 \\
(0.0539)\end{array}$ & $\begin{array}{l}-0.3421^{* * *} \\
(0.0798)\end{array}$ & $\begin{array}{l}-0.2192 \\
(0.1777)\end{array}$ & $\begin{array}{l}-0.2900^{* * *} \\
(0.0271)\end{array}$ \\
\hline INTERCEPT & $\begin{array}{l}4.8432^{\star \star} \\
(0.0318)\end{array}$ & $\begin{array}{l}-0.8626^{*} \\
(0.4519)\end{array}$ & $\begin{array}{l}2.6801^{\star * *} \\
(0.3288)\end{array}$ & $\begin{array}{l}3.2729^{\star \star \star} \\
(0.3794)\end{array}$ & $\begin{array}{l}2.2390^{\star * \star} \\
(0.1166)\end{array}$ \\
\hline R-square & 0.8101 & 0.1722 & 0.1339 & 0.0521 & 0.1744 \\
\hline $\begin{array}{l}F \text { test for no fixed } \\
\text { effects }\end{array}$ & $111.94^{\star \star \star}$ & $4.92^{\star \star \star}$ & $3.42^{\star \star \star}$ & $1.43^{*}$ & $2.01^{* * *}$ \\
\hline No. of obs. & 821 & 821 & 821 & 821 & 821 \\
\hline
\end{tabular}

Note: Year fixed effects were included in all regressions but are not reported to conserve space. Instrument validity was ascertained by checking that the instruments are highly correlated with PRIV_SHARE but weakly correlated with the residuals. 


\section{Table B.5: Partial Privatization and Bank Performance: Placebo Leads (1986-2002)}

The five performance indicators are regressed on the percentage of shares held by the private owners (PRIV_SHARE) - considered contemporaneously as well as placebo leads viz. the value of the variable in the next period. Panel regression technique (within effects) is employed to estimate the model.

\begin{tabular}{|c|c|c|c|c|c|}
\hline & $\log ($ TFP) & OPR & NIM & OCR & SER \\
\hline PRIV_SHARE (LEAD) & $\begin{array}{l}0.0009 \\
(0.0006)\end{array}$ & $\begin{array}{l}0.0241^{\star \star \star} \\
(0.0065)\end{array}$ & $\begin{array}{l}0.0207 \\
(0.0139)\end{array}$ & $\begin{array}{l}0.0012 \\
(0.0042)\end{array}$ & $\begin{array}{l}0.0008 \\
(0.0052)\end{array}$ \\
\hline PRIV_SHARE & $\begin{array}{l}0.0017^{* * *} \\
(0.0004)\end{array}$ & $\begin{array}{l}-0.0083 \\
(0.0058)\end{array}$ & $\begin{array}{l}-0.0028 \\
(0.0056)\end{array}$ & $\begin{array}{l}-0.0049 \\
(0.0075)\end{array}$ & $\begin{array}{l}-0.0023 \\
(0.0051)\end{array}$ \\
\hline PRIV_SECTOR & $\begin{array}{l}-0.0941^{* * *} \\
(0.0172)\end{array}$ & $\begin{array}{l}0.6739^{\star \star \star} \\
(0.1966)\end{array}$ & $\begin{array}{l}-0.3371^{*} \\
(0.1816)\end{array}$ & $\begin{array}{l}-0.0608 \\
(0.5493)\end{array}$ & $\begin{array}{l}-0.5809^{\star \star \star} \\
(0.0955)\end{array}$ \\
\hline PROP_RUR & $\begin{array}{l}0.1045^{\star *} \\
(0.0431)\end{array}$ & $\begin{array}{l}0.5865 \\
(0.5317)\end{array}$ & $\begin{array}{l}1.8364^{* * *} \\
(0.2133)\end{array}$ & $\begin{array}{l}1.2069^{*} \\
(0.6047)\end{array}$ & $\begin{array}{l}1.7833^{\star \star *} \\
(0.2610)\end{array}$ \\
\hline PROP_NINT & $\begin{array}{l}0.0000 \\
(<0.0001)\end{array}$ & $\begin{array}{l}0.0009^{* *} \\
(0.0003)\end{array}$ & $\begin{array}{l}-0.0021^{* * *} \\
(0.0003)\end{array}$ & $\begin{array}{l}-0.0036^{\star * *} \\
(0.0004)\end{array}$ & $\begin{array}{l}-0.0036^{* * *} \\
(0.0003)\end{array}$ \\
\hline SIZE & $\begin{array}{l}-0.0137^{\star * *} \\
(0.0042)\end{array}$ & $\begin{array}{l}0.0550 \\
(0.0502)\end{array}$ & $\begin{array}{l}-0.3442^{\star \star \star} \\
(0.0707)\end{array}$ & $\begin{array}{l}-0.2086 \\
(0.1862)\end{array}$ & $\begin{array}{l}-0.2807^{* \star \star} \\
(0.0305)\end{array}$ \\
\hline INTERCEPT & $\begin{array}{l}4.8106^{\star \star \star} \\
(0.0241)\end{array}$ & $\begin{array}{l}-0.7182^{*} \\
(0.3928)\end{array}$ & $\begin{array}{l}2.7503^{\star \star \star} \\
(0.2342)\end{array}$ & $\begin{array}{l}2.8654^{\star * \star} \\
(0.5262)\end{array}$ & $\begin{array}{l}2.0879^{\star \star \star} \\
(0.1212)\end{array}$ \\
\hline R-square & 0.1830 & 0.0550 & 0.0874 & 0.0143 & 0.1014 \\
\hline No. of obs. & 788 & 799 & 799 & 799 & 799 \\
\hline
\end{tabular}

Note: Numbers in parentheses are robust standard errors (Huber-White). $* * *, * *$ and $*$ indicate statistically significant coefficients at the levels of $1 \%, 5 \%$ and $10 \%$ respectively. 


\section{Notes}

[1] 1994 was the first year of partial privatization in Indian banking. Therefore the time period 1986-2003 offers us a suitable sample period for a before and after comparison. We have 8 years data (1986-1993) before the partial privatization programme began and 10 years data after (1994-2003).

[2] The disclosure guidelines are available on the regulator's website at http://www.sebi.gov.in/guide/dip2009.pdf

[3] The subscript $i$ which stands for individual banks, and the subscript $t$ which stands for years were omitted from equation (2) earlier to preserve clarity of notations. Also the random variables are now specified in lowercase to refer to the error terms for individual banks.

[4] Establishment expenses refer to the wage bill for officers, clerks and other support staff. As wages are jointly bargained by the bank employees association in India, we do not expect the endogeneity of wages to be a serious problem in estimating the cost function.

[5] We may also note that all estimations with the inclusion of branches yield higher values of the log likelihood function as compared with the case when branches are dropped.

[6] Kumbhakar and Sarkar (2003) argue against clubbing the three categories of deposits together. We too feel that since bank policies regarding each category are different and the ratio of these three categories has been varying over time, it is important to treat them as separate variables in the cost function.

[7] The starting year is chosen as 1986 to coincide with the shift of the bank accounting system in India from that based on calendar year to financial year. Starting with 1986, the financial year covers the period from April of one year to March of the following year. Thus the financial year 1986 covers the period from April 1985 to March 1986.

[8] While this result is consistent with Mohan (2005) it appears to contradict the findings of Kumbhakar and Sarkar (2003). However the latter used a sample till 1997 whereas we consider six additional years during which public sector banks considerably outperformed private banks in terms of TFP (see figure 1). 